\title{
Article \\ Modeling and Risk Analysis of Dam-Break Flooding in a Semi-Arid Montane Watershed: A Case Study of the Yabous Dam, Northeastern Algeria
}

\author{
Aissam Gaagai 1 ${ }^{(\mathbb{D}}$, Hani Amir Aouissi ${ }^{1, *(\mathbb{D}}$, Andrey E. Krauklis ${ }^{2}\left(\mathbb{D}\right.$, Juris Burlakovs ${ }^{3}$ (D), Ali Athamena 4 (D), \\ Ivar Zekker ${ }^{5}$, Abderrahmane Boudoukha ${ }^{6}$, Lahcen Benaabidate ${ }^{7}$ (D) and Haroun Chenchouni ${ }^{8,9}$
}

check for updates

Citation: Gaagai, A.; Aouissi, H.A.; Krauklis, A.E.; Burlakovs, J.;

Athamena, A.; Zekker, I.; Boudoukha,

A.; Benaabidate, L.; Chenchouni, $\mathrm{H}$.

Modeling and Risk Analysis of

Dam-Break Flooding in a Semi-Arid

Montane Watershed: A Case Study of

the Yabous Dam, Northeastern

Algeria. Water 2022, 14, 767. https://

doi.org/10.3390/w14050767

Academic Editors: Francesca Aureli,

Andrea Maranzoni and

Gabriella Petaccia

Received: 18 January 2022

Accepted: 25 February 2022

Published: 28 February 2022

Publisher's Note: MDPI stays neutral with regard to jurisdictional claims in published maps and institutional affiliations.

Copyright: (C) 2022 by the authors. Licensee MDPI, Basel, Switzerland. This article is an open access article distributed under the terms and conditions of the Creative Commons Attribution (CC BY) license (https:// creativecommons.org/licenses/by/ $4.0 /)$.
1 Scientific and Technical Research Center on Arid Regions (CRSTRA), Biskra 07000, Algeria; gaagaiaissam37@gmail.com

2 Institute for Mechanics of Materials, University of Latvia, Jelgavas Street 3, LV-1004 Riga, Latvia; andykrauklis@gmail.com

3 Rural Building and Water Management, Estonian University of Life Sciences, Kreutzwaldi 5, 51014 Tartu, Estonia; juris@geo-it.lv

4 Department of Geology, Institute of Earth and Universe Sciences, University of Batna 2, Batna 05078, Algeria; a.athamena@univ-batna2.dz

5 Institute of Chemistry, University of Tartu, 14a Ravila St., 50411 Tartu, Estonia; ivar.zekker@ut.ee

6 Laboratoire de Recherche Appliquée en Hydraulique, University of Batna 2, Batna 05078, Algeria; boudoukha_abderrahmane@yahoo.fr

7 Laboratory of Functional Ecology and Environment Engineering, University of Sidi Mohammed Ben Abdellah, Fez 30500, Morocco; benaabidate@gmail.com

8 Department of Forest Management, Higher National School of Forests, Khenchela 40000, Algeria; chenchouni@gmail.com

9 Laboratory of Natural Resources and Management of Sensitive Environments 'RNAMS', University of Oum-El-Bouaghi, Oum-El-Bouaghi 04000, Algeria

* Correspondence: aouissi.amir@gmail.com; Tel.: +213-662-387-144

Abstract: The risk related to embankment dam breaches needs to be evaluated in order to prepare emergency action plans. The physical and hydrodynamic parameters of the flood wave generated from the dam failure event correspond to various breach parameters, such as width, slope, and formation time. This study aimed to simulate the dam breach failure scenario of the Yabous dam (northeast Algeria) and analyze its influence on the related areas (urban and natural environments) downstream of the dam. The simulation was completed using the sensitivity analysis method to assess the impact of breach parameters and flooding on the dam break scenario. The flood wave propagation associated with the dam break was simulated using the one-dimensional HEC-RAS hydraulic model. This study applied a sensitivity analysis of three breach parameters (slope, width, and formation time) on five sites selected downstream of the embankment dam. The simulation showed that the maximum flow of the flood wave recorded at the level of the breach was $8768 \mathrm{~m}^{3} / \mathrm{s}$, which gradually attenuated along the river course to reach $1972.7 \mathrm{~m}^{3} / \mathrm{s}$ at about $8.5 \mathrm{~km}$ downstream the dam. This study established the map of flood risk areas that illustrated zones threatened by the flooding wave triggered by the dam failure due to extreme rainfall events. The sensitivity analysis showed that flood wave flow, height, and width revealed positive and similar changes for the increases in adjustments $( \pm 25 \%$ and $\pm 50 \%)$ of breach width and slope in the five sites. However, flood wave parameters of breach formation time showed significant trends that changed in the opposite direction compared to breach slope and width. Meanwhile, the adjustments $( \pm 25 \%$ and $\pm 50 \%$ ) of the flood hydrograph did not significantly influence the flood parameters downstream of the dam. In the present study, the HEC-RAS 1-D modeling demonstrated effectiveness in simulating the propagation of flood waves downstream of the dam in the event of dam failure and highlighted the impact of the breach parameters and the flood hydrographical pattern on flood wave parameters. 
Keywords: dam breach parameters; dam failure scenario; flood hazard; flood hydrodynamics; flood simulation; simulated natural hazard

\section{Introduction}

Dam-failure floods are one of the most severe environmental disasters, which result in irreversible ecological, social, and economic consequences. Previous studies assessing dam failure risk revealed that breaching risk and dam failure process can be predicted based on the past dam failure events [1-4]. The reports, which describe dam breaks causing problems around the world, are multiple, for example (1) the Marib dam (Yemen) in 575, (2) an earthen dam near Grenoble (France) in 1219, and (3) in 1923, 1935, and 1985, three dam failure cases in Italy caused the loss of many human lives in the regions of Gleno, Molare, and Stava, respectively [5]. In Algeria, a dam called 'Fergoug I' killed approximately 200 individuals in 1881 in the region of Mascara [6].

In a constantly changing world, dam failure caused by climate change is considered to be an escalating worldwide phenomenon. Usually, within studies related to dams, the dam body (height, width, and slope for earthen dams), including the ancillary structures, are dimensioned and conform to the flood hydrograph. According to recent climate changes, the flood hydrograph recorded at many dams follows an ascending curve compared to previous years [7]. This, therefore, can influence the body of the dam and even its structures. For example, if the spillway does not support the flood input, this flood will systematically discharge at the dam crest to create a breach on the dike. The breach can cause a partial or a total failure of the structure, depending on the resistance of the body of the dam. Therefore, the impact of climate change on dams is reported as a major problem that requires the rigorous and permanent monitoring of dams with the assessment of flooding hazard risk [8,9]. In this sense, in 2015, during the construction of the Yabous dam, built upstream of the city of Yabous (a mountainous area near the province of Khenchela, NE Algeria), an exceptional flood was recorded after heavy rains hit this region. The first author (AG) was a hydrology engineer monitoring the construction project during that period. He clearly observed the destructive effects of this flood on all the structures, particularly the discharge of the flood on the sails of the spillway dissipation basin.

Consequently, a comprehensive management plan for flood plains and watersheds using acute scientific knowledge is necessary to reduce flood damages and prevent socioeconomic losses and environmental degradation [10-12]. Most dam failures and flooding events have resulted from mismanagement practices and/or outdated plans that did not consider or project extreme meteorological events under climate change scenarios that exceed dam dimensioning and reservoir capacity $[13,14]$. Although the methods for investigating flood mitigation are numerous and diverse, flood mitigation remains difficult to fully address because flooding is a complex phenomenon that involves several changing and unpredictable variables [8]. In order to reduce the risks of floods caused by dam failure, scientists and decision makers should consider all of the natural and anthropogenic factors that can predict the risk. In addition, the procedure of studying dam failure must include the delimitation of the risk zone downstream of the dam and investigate all breach formation parameters that may influence this scenario using sensitivity analysis methods to validate simulation modeling outputs accurately [15]. For instance, failure mode, dynamic failure geometry, flow conditions, breach progression, time, materials, and dam type can affect the estimation of the propagation wave resulting from a dam failure. In this regard, previous studies applying sensitivity analysis have highlighted that the parameters mentioned above have various influences on the peak flow in terms of dam geographic location, flood magnitude, etc. [16,17]. In fact, case studies and/or modeling approaches are generally used to predict the parameters of dam failure, where sensitivity analysis is an essential aspect of the use of hydraulic models. The application of sensitivity analysis is vital in decision-making processes to ensure the consistency of the final decision [18]. 
Different simulation scenarios could be visualized through the sensitivity analysis, which is helpful in observing the impact of the parameters changing on the final alternative ranking. The sensitivity analysis allows us to observe how the final assessment is likely to change, and it also measures the magnitude of the change generated by a certain extent of the weight differences in the predicted parameters $[19,20]$.

Several studies have applied analytical models for assessing floods caused by dam failures, including one-dimensional (MIKE11 and HEC-RAS 1-D) and two-dimensional models (FLDWAV, DELFT-FSL, TELEMAC 2-D, MIKE2, and HEC-RAS 2-D). While all these models are designed to analyze and solve the same issue, their principle is not the same. For example, the models MIKE11 and HEC-RAS require the geometrical characteristics of the land, which allow us to draw cross- and perpendicular sections of flow direction and then determine water height and flowing velocity at each point along the river [21-24]. Moreover, the FLDWAV, DELFT-FSL, TELEMAC 2D, MIKE2, and HEC-RAS 2D models require a digital elevation model (DEM), which ensures a continuous assessment of land topography [25]. Gee et al. [26] compared aspects of dam failure using two two-dimensional models (HEC-RAS 2D and FLDWAV) and concluded that the difference in the geometry of the river is the main driver of simulation differences between the two models. In recent years, the simulation of the propagation of flood waves in open channels downstream the dams in failure events was further improved with the development of high-quality DEM and cutting-edge tools for geographic information systems (GIS) [27]. Recent studies on flood inundation modeling involve the application of combined methods, including statistical modeling techniques, remote sensing, and GIS tools [7,28,29].

This study aimed to analyze the dam failure scenario and determine its influence on the urban area downstream of the dam in a semi-arid region in northeast Algeria (Yabous, Khenchela). Using the sensitivity analysis, a simulation highlights the impact of breach parameters and the flood movement on the dam failure scenario in several sites selected downstream the dam, including different structures, i.e., mainly inhabited urban areas, the axis of the dam itself, bridges, etc. In addition, this study aimed to comprehensively model the dam failure process and its consequences using a mixture of datasets (geomatic, hydrological, and hydraulic data) with the application of the one-dimensional Hydrologic Engineering Centers-River Analysis System "HEC-RAS" model. The main benefits of this model are that the floodplain maps can be generated faster; floodplain maps can include several flow scenarios and involve the rapid preparation of geometry data. The HEC-RAS model includes steady and unsteady flow analysis, GIS tools to aide engineering analysis, automated calculation of functions (e.g., the Energy Equation), and the structural validation of hydraulic control features. Specifically, in dam-break flood modeling, the model allows users to see the impact of the breach parameters, such as the width, slope, and time formation using the sensitivity analysis [6]. According to these benefits, HECRAS is the best model in the hydraulic domain compared to other models, which are limited in the domain of flooding and are far from having the same advantages. Using the sensitivity analysis, the study investigated how different sources of input data influence flood simulation reliability. The purposely chosen analysis was carried out by gradually changing the values of each breach parameter in order to observe the ranking order resulting from these changes. This study aimed to: (1) evaluate the characterization of physical and hydrodynamic parameters of the simulated flood wave at different high-risk flood zones downstream of the dam; (2) assess the impact of a dam-break flood on points along the Yabous river; (3) use the sensitivity analysis to assess the impact of the breach parameters on the flood wave propagation in areas downstream of the dam; (4) validate the base model and the ability of HEC-RAS 5.0.7 to simulate the extreme flooding of an area downstream of a dam in the event of failure by applying the HEC-RAS modeling approach. 


\section{Materials and Methods}

\subsection{Study Area and Dam Characteristics}

\subsubsection{Geographic Location and Dam Characteristics}

The Yabous dam $\left(35^{\circ} 23^{\prime} 34.5^{\prime \prime} \mathrm{N}, 06^{\circ} 38^{\prime} 45.8^{\prime \prime}\right.$ E, elevation $=1222.2 \mathrm{~m}$ a.s.l. $)$ is located $63 \mathrm{~km}$ west of Khenchela City at the northern foothills of Jebel Chélia (Figure 1). The region's climate is semi-arid, with annual precipitation varying between 350 and $400 \mathrm{~mm}$, and where evapotranspiration exceeds rainfall due to frequent and prolonged drought episodes, which result in a lack of aquifer recharge [30]. The region's landscapes include montane woodlands, shrubby mountains, and high plains used for rain-fed cereal crops [31].

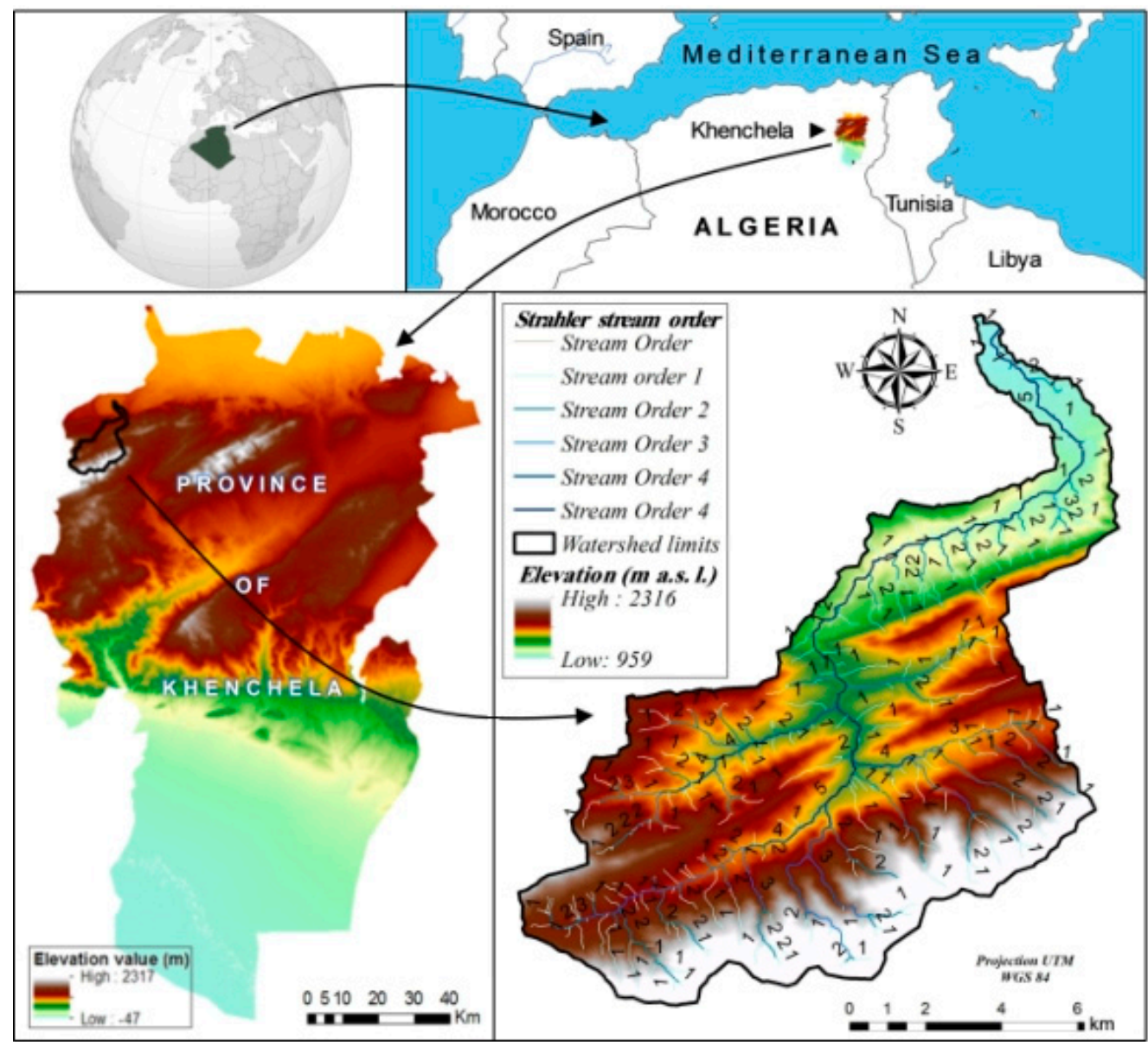

Figure 1. Geographic location and elevation maps of the study area, "Yabous watershed", located at the west of the Province of Khenchela (bottom left map) in northeastern Algeria. The map of the Yabous watershed (bottom right) includes the hydrographic network with Strahler stream orders.

At about $2 \mathrm{~km}$ downstream the dam, the town of Yabous $(\sim 12,000$ inhabitants $)$ is located with a position stretching for $2 \mathrm{~km}$ next to the Yabous river on which the dam was constructed (Figure 2b). The position of Yabous town in relation to the dam represents a real risk to the population in different ways (environmental, social, and economic), especially to the infrastructure, knowing that road \# N45 stretches for more than $8 \mathrm{~km}$ alongside the Yabous river. However, the city of Azla, which is $15 \mathrm{~km}$ away from Yabous dam, is the most exposed village to exceptional floods due to the weak slope at the bed of the wadi of Yabous. Small floods have left traces on this village, so the consequences will be irreversible if the dam breaks. Moreover, the largest plain of Yabous, also known by the name "SEKOUM," with a surface of 1839 ha, can also be exposed to this flood (Figure 2a). In addition, the locals became very concerned about the hazard that the dam presents in case of failure, which urged the authorities to create an effective alarm system on the downstream zones prone 
to flooding associated with dam rupture events. The climate in the region is semi-arid, characterized by hot, dry summers and cold rainy winters, accompanied by snowfall on the mountains. The average annual temperature is around $14.80^{\circ} \mathrm{C}$. However, the average annual evaporation varies between 1300 and $1400 \mathrm{~mm}$. The monthly evaporation of the locality of Yabous varies from 105 to $240 \mathrm{~mm}$ between April and September. Its monthly distribution shows steady growth from April to July. The period from October to March totals $26 \%$ of the annual average. Regarding rainfall, the average annual rainfall is between 350 and $400 \mathrm{~mm}$. The Yabous station shows that the region is characterized by two rainy periods. The first extends from September to November, while the second goes from March to May.
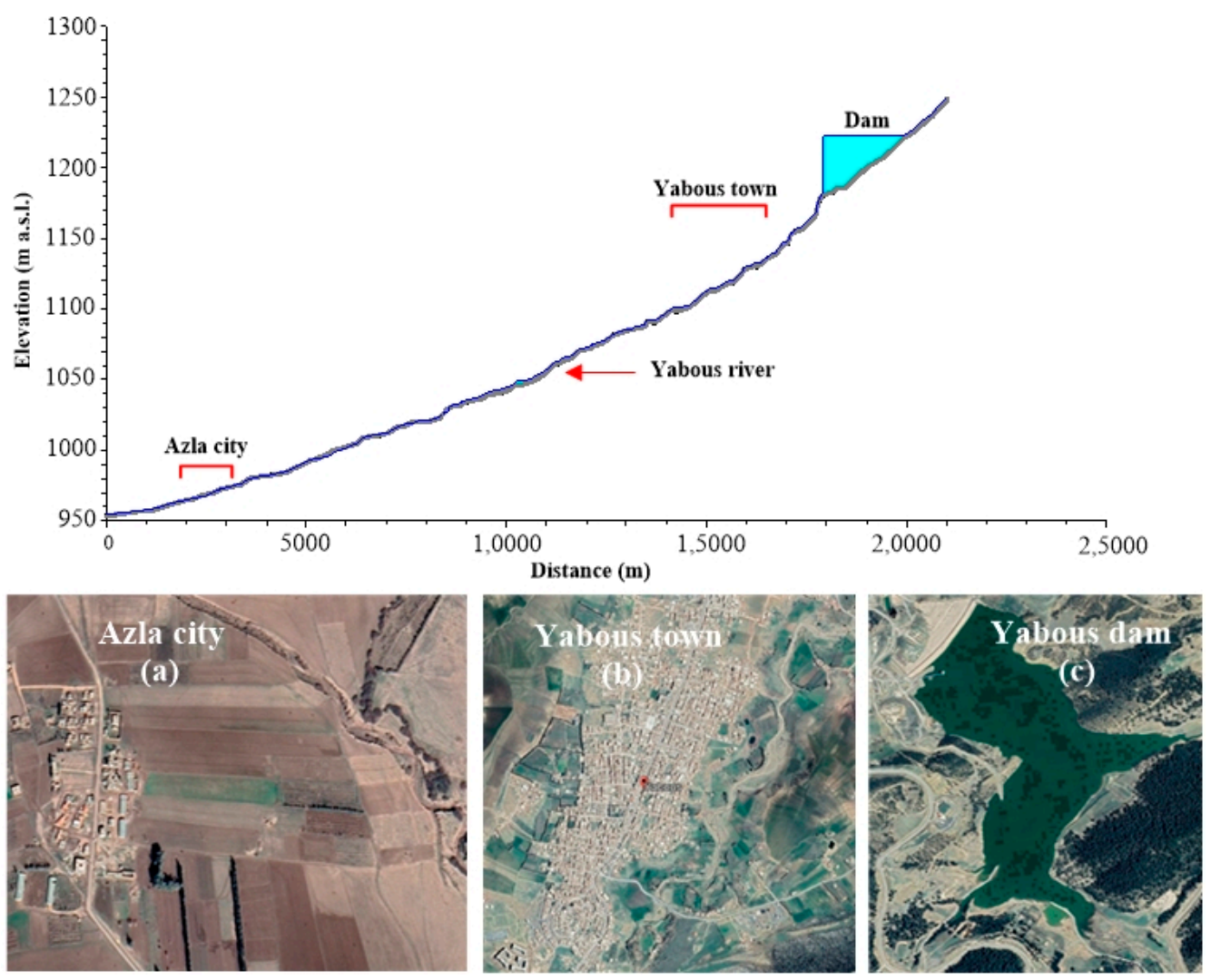

Figure 2. Longitudinal profile of Yabous river and town located downstream of the dam reservoir. (a) Azla city $15 \mathrm{Km}$ away from Yabous dam, (b) Yabous town $2 \mathrm{Km}$ away from Yabous dam and (c) Yabous dam.

Technically, the dam was built of earth with a clay core, and the dam height $=43 \mathrm{~m}$, span $=460 \mathrm{~m}$, and crest width $=10 \mathrm{~m}$. Its storage capacity $\approx 7.5$ million $\mathrm{m}^{3}$, and the volume now $\approx 5.7$ million $\mathrm{m}^{3}$ of water. Dam water is not yet exploited, but it is projected to supply 33,000 inhabitants of surrounding regions with drinking water $\left(\sim 1\right.$ million $\mathrm{m}^{3}$, with a daily allocation of $\left.4800 \mathrm{~m}^{3}\right)$ and irrigation water $\left(\sim 2\right.$ million $\left.\mathrm{m}^{3}\right)$ destined for agricultural lands (>500 ha) of mainly apple orchards.

\subsubsection{Aspect and Slope Features}

The slope map of the study area (Figure 3A) was established based on ASTER GDEMv2 data using the spatial analysis tool in ArcGIS-10.5 (see details in Section 2.2.1). The slope grid is identified as the maximum rate of change in the value of each cell relative to its neighboring cells. The slope degree of the Yabous watershed varies from $12^{\circ}$ to $61^{\circ}$. Terrains with steep slopes result in rapid runoff and an increased erosion rate (potential loss of soil) with less groundwater recharge potential. This kind of slope is located in the southern part of the Yabous basin, which is at extremely severe risk of soil erosion. Generally, the 
aspect refers to the orientation of the slope. The map of aspects of the Yabous watershed (Figure 3B) displays clearly that the south-facing slopes dominate the basin. Consequently, these slopes have a lower evaporation rate and higher moisture content, even if some parts fall to the northeast, which has a lower moisture content and higher evaporation rate.

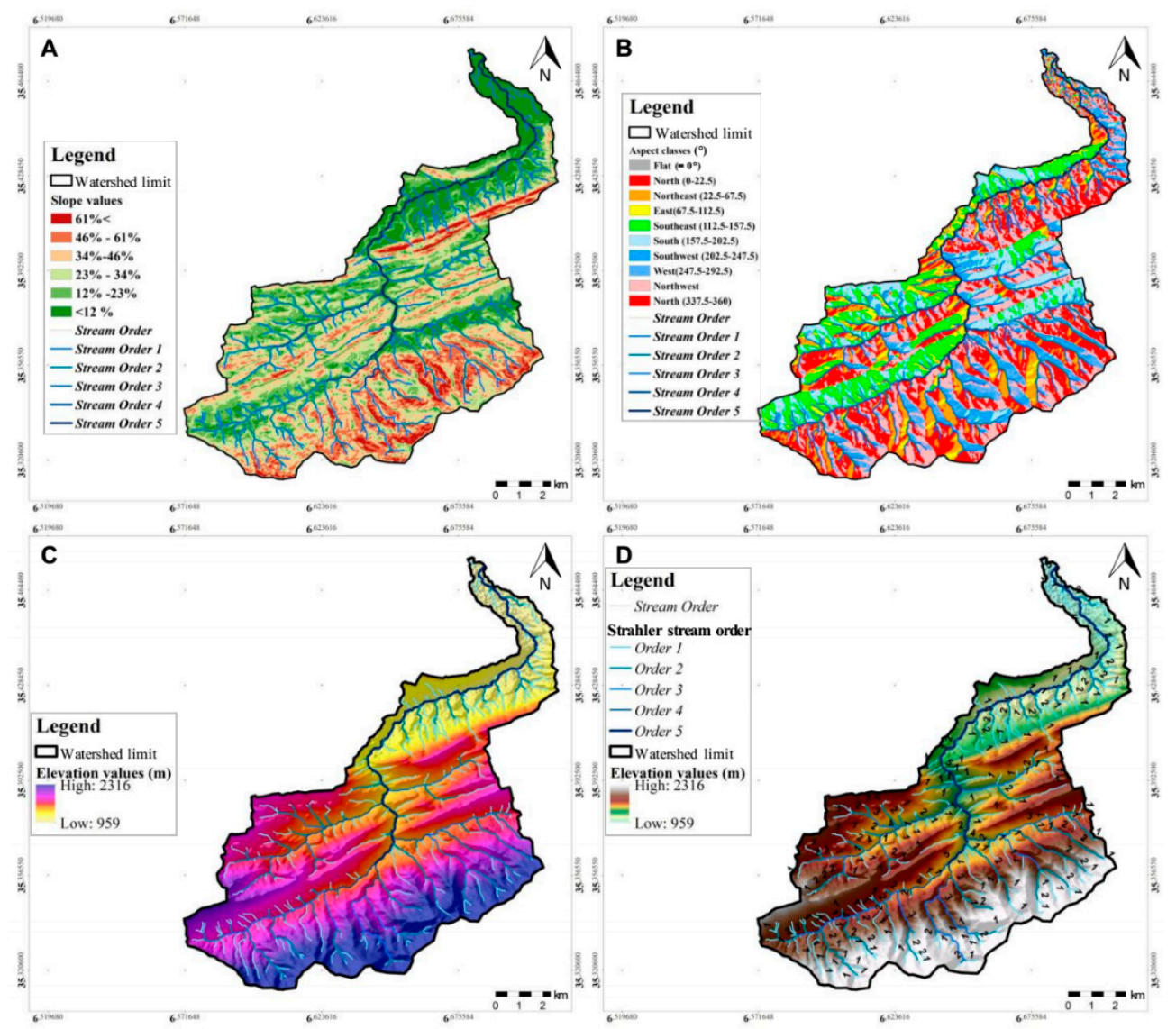

Figure 3. Maps of Yabous watershed displaying (A) slope gradient, (B) surface aspects, (C) altitude above sea level, and (D) hydrographic network with Strahler stream orders.

\subsubsection{Relief and Hydrographic Network}

The relief plays an important role in defining the morphometric variables used to evaluate geomorphological characteristics of any topography. The highest terrain altitude was determined to be $2316 \mathrm{~m}$ a.s.l., while the lowest value of elevation was recorded as $960 \mathrm{~m}$ a.s.l. (Figure 3C). According to the "top-down" system developed by Strahler (1957), stream orders of the Yabous basin were classified in up to five orders with a predominance of order 1 and then order 2. The number of streams of different orders and the total number of streams in the basin were counted and calculated in the GIS platform. During this procedure, it appeared that the amount of flow gradually decreases as the order of the flows increases. The variation in the size and order of streams in the basin tributaries depend primarily on the region's physiographic, geomorphological, and geological conditions. In total, 314 streamlines were recognized using five stream orders in the entire watershed of the Yabous river (Figure 3D).

\subsection{Data Collection, Processing, and Modeling Approach}

\subsubsection{Data Processing}

The satellite image of the study area was retrieved from the ASTER (Advanced Spaceborne Thermal Emission and Reflection Radiometer) satellite at $30 \mathrm{~m}$ spatial resolution. This image was used to build the DEM of the study area and extract the required data for the assessment of the areas downstream of the dam at risk of flooding in the event of failure. 
The data were imported into ArcGIS software (version 10.5) to generate the final DEM and obtain additional mapping information, such as watershed limits, the hydrographic network used to define all the streams, altitude range, and relative position of slopes (Figure 4).

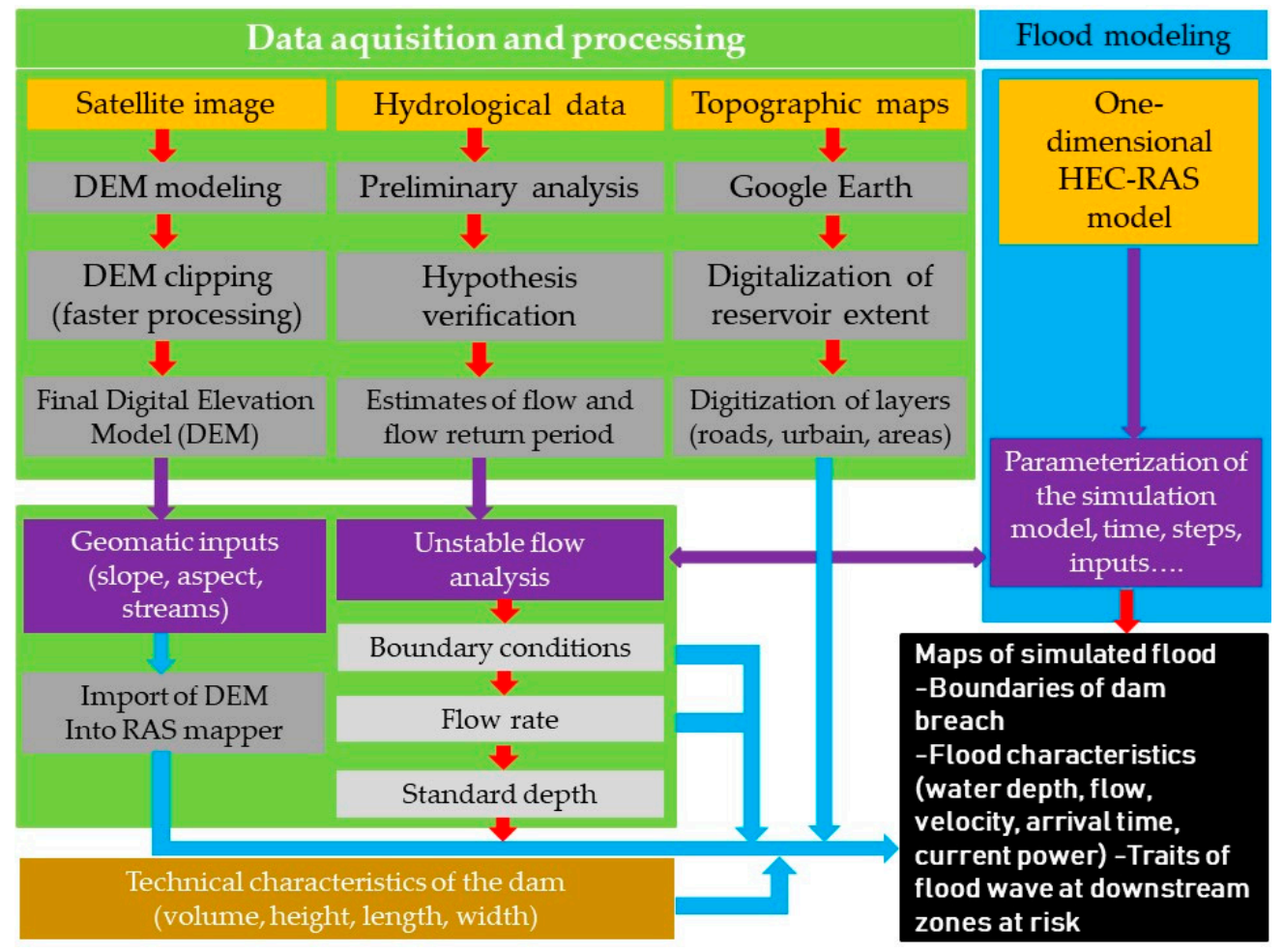

Figure 4. Methodological flowchart applied in Yabous watershed (NE Algeria) during the simulation of a dam-failure flood using 1-D HEC-RAS hydraulic model.

The flood simulation was implemented using a one-dimensional HEC-RAS model [32], which determined several physical characteristics of the flood wave, including wave height, maximum flow 'Qmax', and the velocity of the flood wave. HEC-RAS is undoubtedly one of the most used one-dimensional models because it includes other applications, such as water temperature modeling and sediment transport simulation. Since 2003, it has been developed to simulate dam failure [33].

In addition to the geomatic data described above, the simulation of the flood wave propagation downstream of the Yabous dam along the Yabous river using the HEC-RAS model was carried out using geometric, geotechnical, and hydraulic data (boundary conditions) (Figure 4).

\subsubsection{Dam Dimensions}

The body of the Yabous dam has the form of a zoned earth dike with a watertight clay core. Its crest length is $480 \mathrm{~m}$, and its width is $7 \mathrm{~m}$. The central core of the dike (zone 1) is made up of clay materials. The upstream recharge consists of argillaceous colluvium and wadi alluvium. In addition, the downstream area is made up of alluvial material from the wadi resting on a sand filter mat to protect the crumble, colluvial, and marl foundation (Figure 5). 


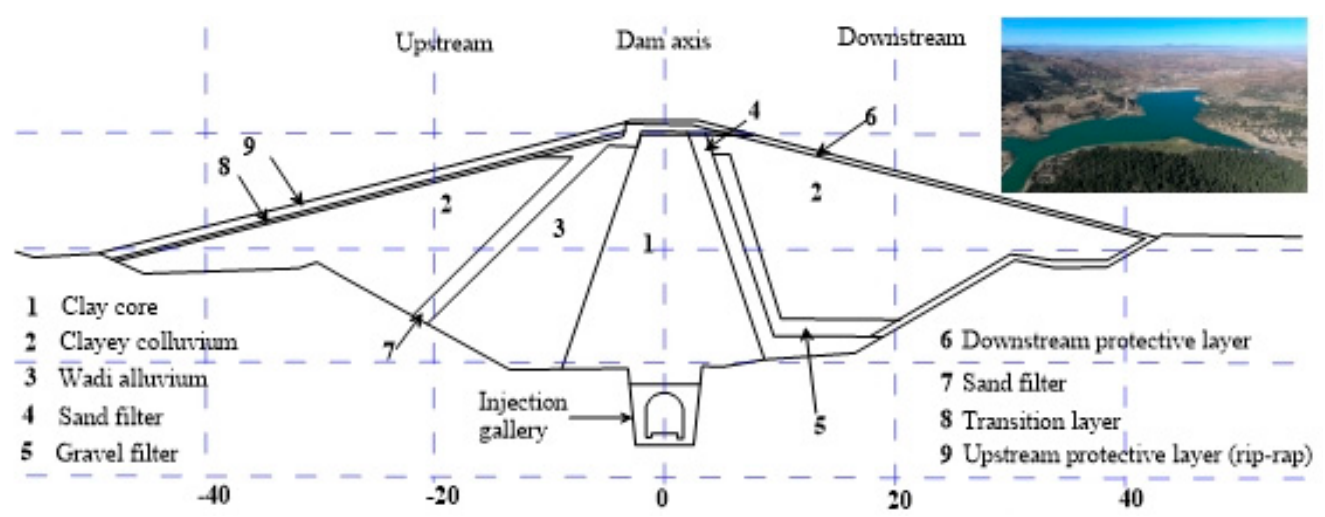

Figure 5. Dam dimension.

The embankments are protected by limestone riprap. The limestones are dense and contribute to the protection with their acceptable mechanical characteristics. The backfill's overall volume of the dam body is $1,418,810.00 \mathrm{~m}^{3}$. There is a temporary tunnel-type diversion gallery that is $373.00 \mathrm{~m}$ long and $7.00 \mathrm{~m}$ in diameter. The tunnel has a discharging capacity of the planned (millennial) flood qualified at $485.00 \mathrm{~m}^{3} / \mathrm{s}$. Moreover, a tulip-type spillway, with a well connected to the temporary diversion gallery ending in a stepped dissipation basin. The spillway is capable of evacuating the designed flood. The outer diameter of the spillway's weir and that of the drum are $16.00 \mathrm{~m}$ and $7.00 \mathrm{~m}$, respectively. Lastly, a circular water intake tower and its access walkway comprise three (03) stepped water intakes and a bottom drain.

\subsubsection{Flood History}

The site experienced an exceptional flood, with a significant flow, on 8 February 2015. The dam body and its annexes were unable to cope with the flow. Take the designed intake tower, the spillway, and the dissipation basin as an example. The evidence showed that the flow occupied the section of the dissipation basin and even discharged over its walls. According to Figure 6, the flooding caused the deterioration of the following structures: (i) The drainage channel to the bottom drain: the gabion mat protecting the raft from the inlet channel to the bottom drain was completely damaged (Figure 6A). (ii) The restitution channel at the outlet of the dissipation basin: the protective riprap of the dissipation basin's downstream part underwent significant degradation. Similarly, the massive support for the potable water and the irrigation pipes endured severe damage (Figure 6B).

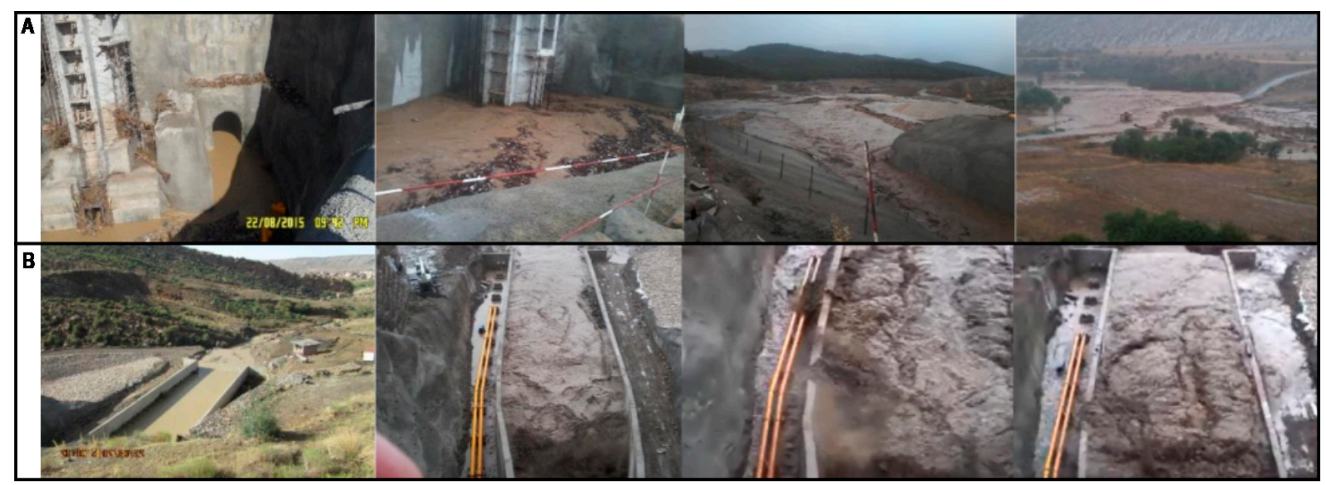

Figure 6. Historic flood of Yabous river. (A) The gabion mat protecting the raft from the inlet channel to the bottom drain was completely damaged. (B) The protective riprap of the dissipation basin's downstream part suffered significant degradation. Similarly, the massive support for the potable water and the irrigation pipes endured severe damage. 


\subsubsection{Geometric Data}

Cross-sections were placed along the Yabous river in order to estimate the height of the flood wave downstream of the dam at different sites, which were selected based on the change of the river's direction, width, slope, and land uses, such as agricultural lands, the presence of urban areas, and infrastructures, such as bridges and roads. Cross-sections consisted of either a short section for a narrow valley or an elongated section that functions whenever the simulated water level exceeds the height of that section. This pattern was implemented in order to ensure that the height of the flood wave resulting from a possible dam failure does not exceed the cross-sections. Using RAS Mapper (version 5.0.7), the cross-sections were converted into points supplemented with elevation values retrieved from the DEM data that were required for HEC-RAS analysis. Then, the model calculated the distance between every two cross-sections. Transversal quality control was carried out on the geometric data to ensure that no inexact information was imported. Accordingly, if required, a few cross-sections were edited in the graphic cross-section editor [34]. In total, 122 cross-sections were implemented with a total length of $21.009 \mathrm{~km}$ along Yabous river, with the distance between two cross-sections ranging from 50 to $150 \mathrm{~m}$, and 4104 cross-sections interpolated using the model to ensure a good simulation of the flood wave propagation downstream of the dam (Figure $7 \mathrm{a}, \mathrm{b}$ ). These cross-sections were implemented according to: (1) the existing structures downstream of the dam; (2) the implementation of the agglomeration zones; (3) the change in the direction of the river; (4) the slope of the river; (5) the geometry of the basin. Seven sites located along an altitudinal gradient downstream of the dam were selected to assess the impact of dam-failure flood, i.e., (S1) axis of the dam, (S2) upstream urban area (Yabous town), (S3) bridge 1 (Figure 7c), (S4) bridge 2 (Figure 7d), (S5) downstream urban area, (S6) upstream Azla city, and (S7) downstream Azla city, which correspond to the cross-sections at 17,945, 17,207, 16,590, 14,546, 14,461, 2877 , and 2480, respectively.

\subsubsection{Geological/Geotechnical Data}

The study area is part of the eastern Saharan Atlas. The area's intermediate position between the Saharan platform and the mobile Tellian domain explains the facies variations it presents (Figure 8). The Cretaceous formations characterized by the internal platform facies on the southern and southwestern margins of the basin pass to marl-limestone series to faunas and pelagic micro-faunas toward the north and northeast. The Yabous dam site is based on a tectonic accident stalling in an NS direction, which may affect its stability. The town of Yabous is located at an altitude of 900-1100 m and delimits the Aurès massif to the north. Its surface is covered by a Quaternary piedmont glacis, largely encrusted, which hides a powerful series (approximately $700 \mathrm{~m}$ ) of sandstone sediments dated from the Tortonian Miocene. The locality of Yabous presents several types of fault structures from both pre- and post-Miocene eras. The latter appeared in Cretaceous and Miocene formations.

Due to its high precision, Manning's roughness coefficient was used in the HECRAS hydraulic model to compute water surface elevation. According to the classification of [35], two types of land use classes were selected for the study area. Then, the values of Manning's coefficient were adapted according to this classification. The Yabous riverbed is made of uniform gravels with rugged banks. According to Chow's classification of the river substrate, a Manning coefficient value of 0.0356 was retained for the entire riverbed in the study area. However, the Manning coefficient of agricultural land on the left and right sides of the riverbed is 0.1 . 


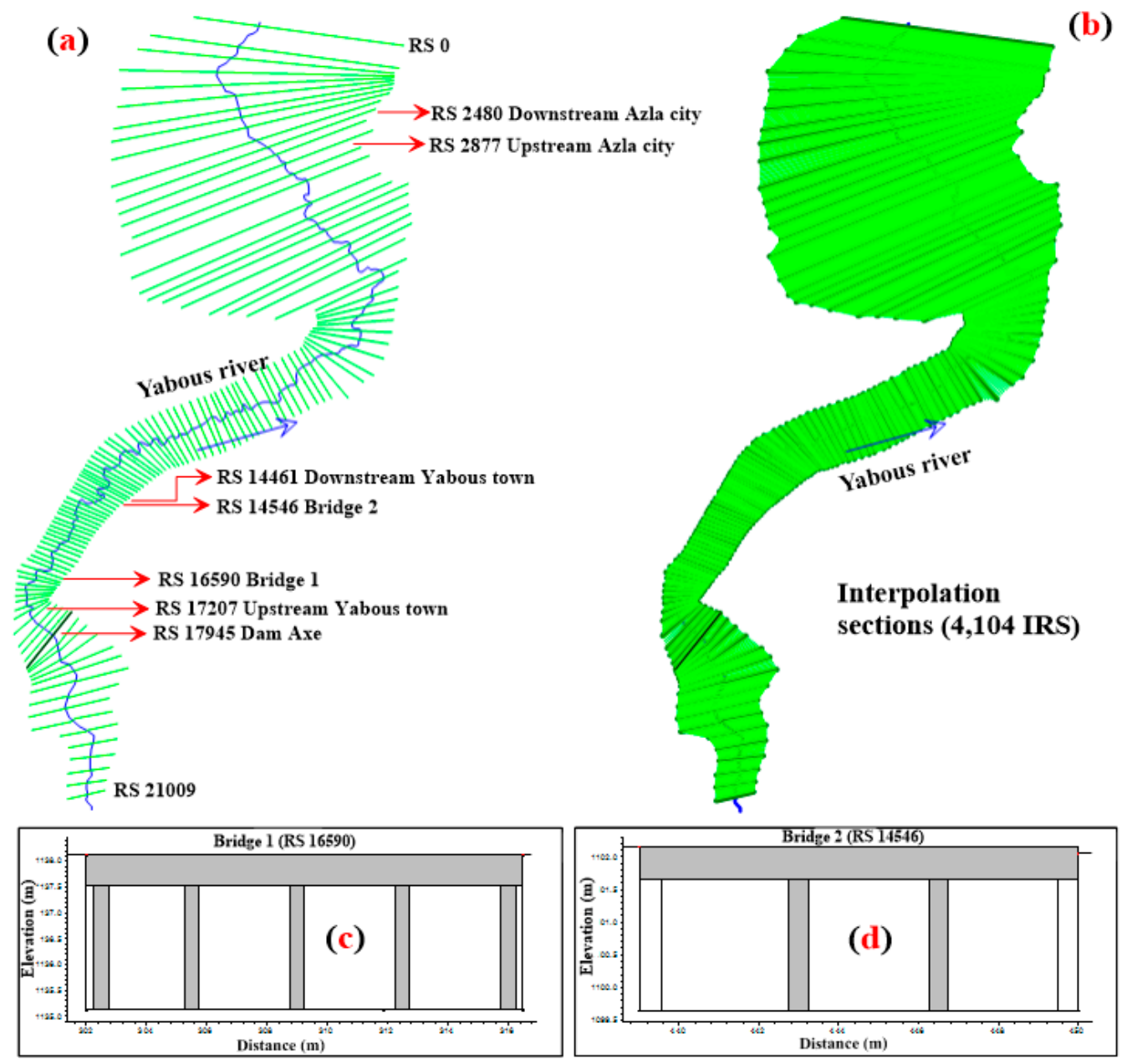

Figure 7. Location of cross-sections ( $n=89,(a))$ and interpolated sections $(n=1267,(b))$ along the river downstream of Yabous Dam in northeastern Algeria. Numbers RS represent the cross-sections. Cross-sections Bridge 1 (c) and cross-sections Bridge 2 (d).
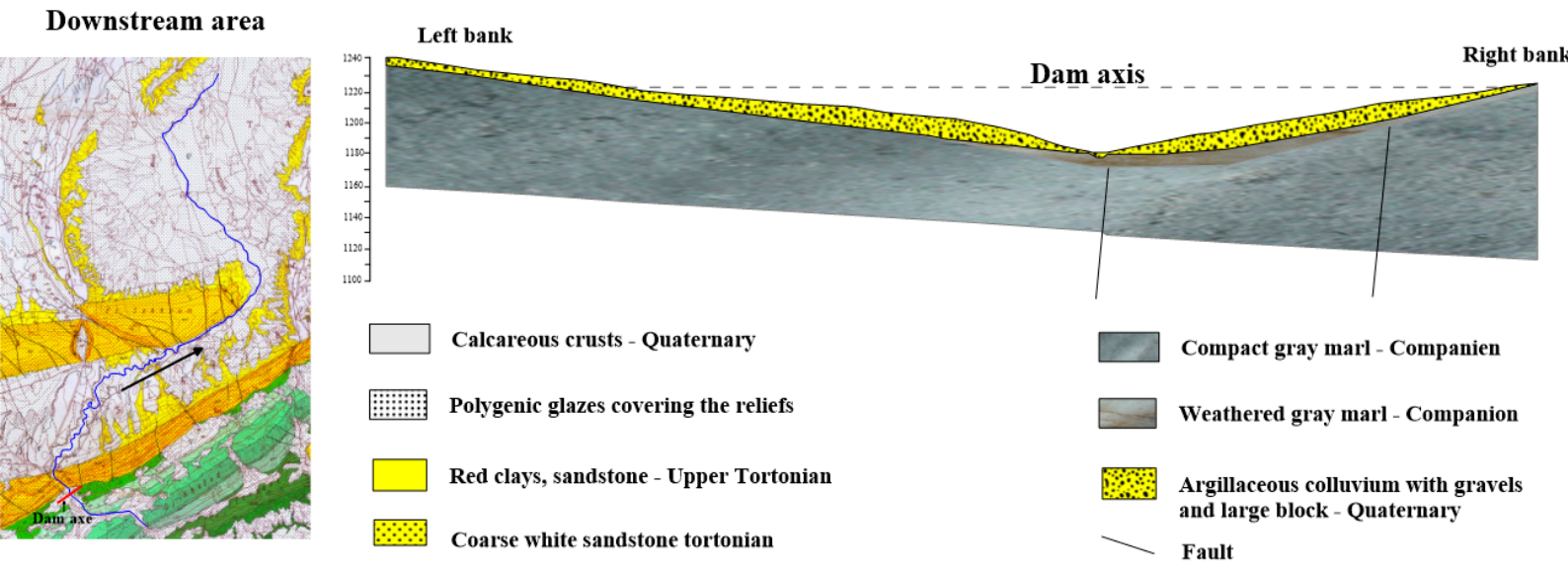

Figure 8. Geological maps of the study area, "Yabous watershed", located west the Province of Khenchela (bottom-left map) in northeastern Algeria.

\subsubsection{Hydraulic Data}

After processing the geometric data, the initial and boundary conditions required for the HEC-RAS model were: First, the initial condition $\left(Q=3 \mathrm{~m}^{3} / \mathrm{s}\right)$. Second, data from the millennial series flood hydrograph with a maximum discharge of $485 \mathrm{~m}^{3} / \mathrm{s}$ (Figure 9). 
Third, the normal depth value that was obtained from the slope and calculated from the profile of the river using the HEC-RAS model. The normal depth of the Yabous River, in this study, was established at 0.002. Once the previous information was settled and data were processed, the model was launched to simulate the propagation of flood waves downstream of the dam.

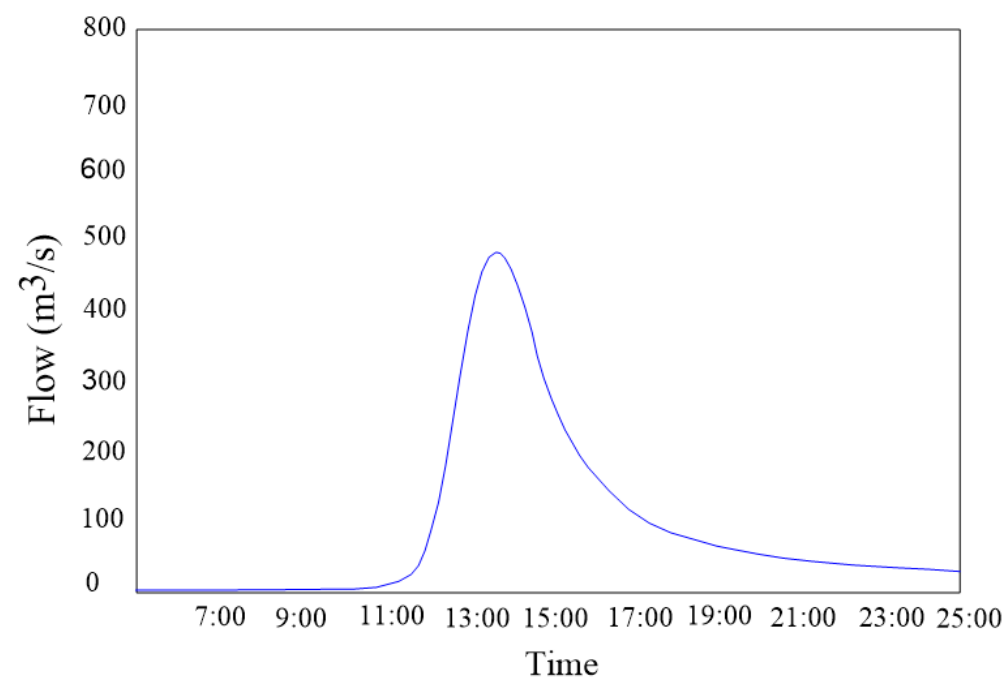

Figure 9. Flood hydrograph of Yabous river.

\subsection{HEC-RAS Flood Model}

As a reminder, HEC-RAS is a hydraulic model designed by the US Corporation Engineers Hydraulic Engineering Centre to model river flow [36]. It is a well-established and well-tested model globally and is sometimes used as benchmarked against the performance of other hydrodynamic model simulation software [37]. This software permits users to estimate water surface profiles along a river with steady and unsteady flow river hydraulic calculations, including sediment transport modeling [38]. Energy and momentum Equations (1) and (2) are used to derive the 1-D Saint Venant equation in generating steady and unsteady state flow water surface profile simulations within HEC-RAS using an implicit finite different method [37].

$$
\begin{gathered}
\frac{\delta A}{\delta t}+\frac{\delta S}{\delta t}+\frac{\delta Q}{\delta x}-q=0 \\
\frac{\delta Q}{\delta t}+\frac{\delta V Q}{\delta x}+g A\left(\frac{\delta z}{\delta x}+S_{f}\right)=0
\end{gathered}
$$

where $A$ is the cross-sectional area, $t$ is the time, $S$ is the ineffective flow area, $Q$ is the discharge, $q$ is the inflow per unit area, $x$ is the distance along the channel, $V$ is the velocity, $z$ is the elevation, $S f$ is the friction slope, and $g$ is the gravitational acceleration.

The unsteady flow simulation component in the HEC-RAS modeling system is capable of simulating 1-D unsteady flow through a full network of open channels. In this study, 1-D HEC-RAS version 5.0.7 is used to model the flood wave in a downstream dam in the event of failure. This current version of HEC-RAS is able to perform 1-D hydrodynamic modeling and an interesting flood inundation mapping tool directly within HEC-RAS 5.0.7 through RAS Mapper.

\subsubsection{One-Dimensional HEC-RAS Modeling}

It is known that a good hydraulic model requires good geometry and flow data input. However, the goodness of the simulations is also affected by model type, i.e., onedimensional (1-D), two-dimensional (2-D), or combined (1D/2D) types. A 1-D model is still the most used to simulate flow in the main river channel and, in certain cases, very 
effective in predicting flood extent [39]. One-dimensional modeling also has computational efficiency and simple parameterization in dealing with flows in large and complex networks and is favored even more specifically in developing countries [40]. Nevertheless, this simple model has some drawbacks when simulating a 2-D flow path in a large floodplain. In short, a 1-D model is robust, economical, provides valuable information on water profile properties, and is a popularly preferred alternative, as long as the flow paths can be identified $[40,41]$. The hydraulic simulation by HEC RAS allows the visualization and spatial analysis of the results, such as the limits of the flood zones, the water levels of the flood, etc. Therefore, it is considered to be a decision-making tool par excellence for flood risk management. The HEC RAS modeling is well suited to help in carrying out dam failure analyses [6]. The most significant advantage in the 1-D HEC-RAS model is that in dam-break flood modeling, the model allows users to see the impact of the breach parameters, such as the width, slope, and time formation, using the sensitivity analysis [6].

In 1-D river hydraulic modeling, all water flows are assumed to flow in a longitudinal direction. One-dimensional models represent the terrain as a sequence of cross-sections and simulate the flow in order to provide estimates of flow parameters, such as flow velocity and water depth [42]. To simplify the computation, HEC-RAS assumed a horizontal water surface at each cross-section normal to the direction of the flow such that the momentum exchange between the channel and the floodplain can be neglected [43]. The one-dimensional equations of motion then become Equations (3) and (4):

$$
\begin{gathered}
\frac{\partial A}{\partial t}+\frac{\partial(\varnothing Q)}{\partial x_{c}}+\frac{\partial[(1-\varnothing) Q]}{\partial x_{f}}=0 \\
\frac{\partial Q}{\partial t}+\frac{\partial\left(\frac{\varnothing^{2} Q^{2}}{A_{c}}\right)}{\partial x_{c}}+\frac{\partial\left[(1-\varnothing)^{2} Q^{2} / A_{f}\right]}{\partial x_{f}}+g A_{c}\left[\frac{\partial Z}{\partial x_{c}}+S_{f c}\right]+g A_{f}\left[\frac{\partial Z}{\partial x_{f}}+S_{f f}\right]=0
\end{gathered}
$$

where $Q$ is the total flow, $A$ is the flow area, $\varnothing$ is the quotient of channel conveyance over the total conveyance, $z$ is the elevation of water surface, and $S f$ is the friction slope, in which the subscripts $c$ and $f$ refer to the channel and floodplain, respectively. The 1-D model unsteady flow equations were solved using a four-point implicit scheme, where the space derivatives and function values were evaluated at an interior point $(n+\theta) \Delta t$.

The performance of 1-D modeling in the hydraulic simulation is tested in a number of studies, such as Horritt and Bates [44], who concluded that the 1-D model is capable of giving a good estimation of flood level and travel time and can be used for the prediction of flood extent. In a recent study, Timbadiya et al. [45] studied the 1-D hydrodynamic model for two flood events and proposed that the flood level predicted was computationally satisfactory on the basis of the root mean square error validation. In addition, Pramanik et al. [46] simulated a 1-D model of the Brahmani River using geometry from a combination of surveyed and digital elevation models (DEM). At the same time, Patel et al. [47] executed the 1-D model for an $11 \mathrm{~km}$ of the lower part of Ambica River, with 359 surveyed channel cross-section inputs that highlighted the importance of accurate geometry data in 1-D hydrodynamic model. These studies confirm the cost effectiveness, reduced complexity, and reliable prediction of water level along the river of the 1-D model [38]. In this paper, the 1-D modeling approach was applied to validate the base model and ability of HEC-RAS 5.0.7 to simulate extreme events of a flood wave in a downstream dam in the event of failure.

\subsubsection{Dam Break Scenario}

In this study, we assumed that a historic flood could occur in the watershed of the Yabous dam and that the reservoir level of this dam is at a normal level. The flood wave created by the dam failure extended to the end of the study area. Due to the location of the lateral works, with very steep terrain and mountains downstream of the Yabous dam, the severity of the flood waves would be reduced spatially and temporally. The flood wave 
would change its parameters (width, height, and discharge) because of the geometry of the area downstream of the dam. In order to perform the unsteady flow analysis with the failure scenario [48,49], six steps were followed: (a) the geometry model was created in HEC-RAS 5.0. 7 using RAS Mapper, (b) dam characteristics were entered in order to create the dam, (c) failure parameters were calculated, (d) roughness data were entered, (e) the influx data were defined, and (f) the computation time was calculated $[43,50]$.

The first step was to identify the geometry of the area, including drawing the wadi boundary and cross-sections over the entire study area and, in particular, the sections desired to see the impact of the flood wave on them. The geometric model represents a network where each section contains geometric information about the underlying terrain. In the 1-D model, each cross-section is similar to each design cell in the 2-D model, and a property table is created for each section [43,51]. More than 122 calculation sections, 4104 interpolation sections, and a 1-D flow area were created based on the extent of the flood zone with an area of 2389 ha for the present study. The flood flow is calculated based on the data obtained from the underlying terrain, such as area, elevation-volume relationship, roughness, and maximum, minimum, and average elevations. To obtain an accurate representation of the flood wave, the size of the cross-sections must be chosen $[52,53]$. The next step was to introduce the characteristics of the dam: dam length $480 \mathrm{~m}$; dam crest width $7 \mathrm{~m}$; dam height $50 \mathrm{~m}$. Once the dam was created, the following parameters were introduced to breach the dam: center station, final bottom elevation, final bottom width, right- and left-side slope, and breach weir coefficient (see next Section 2.3.3).

For unsteady flow data, boundary conditions and initial conditions have been defined. As initial conditions, an initial flow is given as $Q_{0}=3 \mathrm{~m}^{3} / \mathrm{s}$. As boundary conditions, we assumed that the reservoir has a maximum water volume (100\% fill) for the return interval of $0.01 \%$ (1000 years), which corresponds to a flow rate of $485 \mathrm{~m}^{3} / \mathrm{s}$. For this scenario, a normal depth (the energy slope of the riverbed) was defined for the 1-D flow zone [51].

The last step in the dam failure modeling process was to calculate the computation time to ensure the stability of the hydraulic model. The main effect of a bad computation time is the instability of the model [50]. Specifically, if the time step is too large, in addition to the instability of the model, an attenuation peak can occur. In addition, if the time step is too small, the calculation period will be very long. Nevertheless, in order to estimate the computation time, the current condition was used (Equation (5)) [50,51,54].

$$
C=\frac{V_{w} \Delta T}{\Delta X} \leq 1, \quad \Delta T=\frac{\Delta x}{V_{w}}, \quad V_{w}=\frac{d Q}{d A^{\prime}}
$$

where $C$ is the current, $\Delta T$ is the time step (s), $\Delta x$ is the distance step in $\mathrm{m}, V_{w}$ is the flood wave speed $(\mathrm{m} / \mathrm{s}), d Q$ is the change in flow rate over a short time interval $(\mathrm{Q} 2-\mathrm{Q} 1)$, and $d A$ is the change in the effective section over a short time interval (A2 - A1). According to Equation (5), a time step of $3 \mathrm{~s}$ was used to run the model.

\subsubsection{Estimation of Dam Breach Parameters}

Risk assessments of embankment dam failure frequently require predicting the basic temporal and geometrical parameters of a breach to estimate peak breach flows. This flow varies depending on the breach parameters, such as the slope, width, and time of breach formation [55]. The most used models predicting these relationships have been developed from statistical analyses involving historical data of dam failures. The prediction uncertainties of these methods are broadly large, but still never concretely quantified [23]. Among many methods used to predict the parameters of dam breach, four methods were selected in this investigation [56-59] (Table 1). Regarding the adaptation of these methods for the regression analysis, a prediction analysis of these methods is important to estimate their performance. As an example, Froehlich [58,59] used parameters of 63 dam breach cases to develop their relationships (Equations (6)-(9)), whereas Von Thun and Gillette [57] used 57 dam breach cases (Equations (10) and (11)), and Macdonald and Langridge-Monopolis [56] used 42 dam breach cases (Equations (12)-(14)). The use 
of uncertainties of breach parameter estimates obtained from one of these methods is necessary to determine their impacts on the risk of dam failure. These uncertainties are assessed so that reasonable limits of breach parameter values can be estimated and used to determine the reliability of the flood hydrographs predicted by the hydraulic structures, as well as the flood wave peaks at the defined sites downstream of the dam. The four above-mentioned methods exist in HEC-RAS version 5.0.7. The HEC-RAS model was used to calculate each method's average width, lateral slope, and breach formation time once its requirements and input data were filled.

$$
\begin{gathered}
B_{\text {ave }}=15 K_{0} V_{w}^{0.32} h_{b}^{0.19} \\
t_{f}=3.84 V_{w}^{0.53} h_{b}^{-0.9} \\
B_{\text {ave }}=0.27 K_{0} V_{w}^{0.32} h_{b}^{0.04} \\
t_{f}=63.2 \sqrt{\left(\frac{V_{w}}{g h_{b}^{2}}\right)} \\
B_{\text {ave }}=2.5 h_{w}+C_{b} \\
t_{f}=\frac{B_{\text {ave }}}{4 h_{w}} \\
V_{\text {eroded }}=0.00348\left(V_{\text {out }} h_{w}\right)^{0.852} \\
t_{f}=0.0179\left(V_{\text {eroded }}\right)^{0.364} \\
V_{b}=\frac{V_{\text {eroded }}-h_{b}^{2}\left(C Z_{b}+\frac{h_{b} Z_{b} Z_{3}}{3}\right)}{h_{b}\left(C+\frac{h_{b} Z_{3}}{2}\right)}
\end{gathered}
$$

where: $B_{\text {ave }}=$ average width $(\mathrm{m}) ; W_{b}$ is the final bottom width; $h_{w}=$ depth of water above the bottom of the breach $(\mathrm{m}) ; h_{b}=$ height from the top of the dam to the bottom of the breach $(\mathrm{m}) ; Z=$ breach embankment slope $(\mathrm{m}) ; B=$ lower width $(\mathrm{m}) ; t_{f}=$ breach formation time (h); $V_{w}=$ reservoir volume at time of failure $\left(\mathrm{m}^{3}\right) ; K_{0}=$ constant $(1.3$ for overtopping failures, 1.0 for piping); $V_{\text {eroded }}=$ volume of material eroded from the dam embankment $\left(\mathrm{m}^{3}\right) ; V_{\text {out }}=$ volume of water that passes through the breach $\left(\mathrm{m}^{3}\right) ; C=$ crest width of the top of dam (m); $Z_{3}=Z_{1}+Z_{2} ; Z_{1}=$ average slope $\left(Z_{1}: 1\right)$ of the upstream face of the dam; $Z_{2}=$ average slope $\left(Z_{2}: 1\right)$ of the downstream face of the dam; $Z_{b}=$ side slopes of the breach $\left(Z_{b}: 1\right)$, which are 0.5 for the MacDonald method; $C_{b}=$ coefficient, which is a function of reservoir size.

Table 1. Parameters of the flow simulation for four dam breach parameter prediction methods using the HEC-RAS in modeling dam-break flood of Yabous dam in northeastern Algeria.

\begin{tabular}{ccccc}
\hline \multirow{2}{*}{ Prediction Methods for Dam Breach Parameters } & \multicolumn{3}{c}{ Flow Parameters } \\
\cline { 2 - 5 } & Width (m) & Slope & Flood Time (h) & Q (m $\left.{ }^{3} / \mathbf{s}\right)$ \\
\hline Macdonald and Langridge-Monopolis (1984) & 14 & 0.5 & 1.10 & 4400.2 \\
Von Thun and Gillete (1990) & 54 & 0.5 & 0.47 & 8767.9 \\
Froehlich (1995) & 26 & 1.4 & 0.42 & 7841.1 \\
Froehlich (2008) & 26 & 1.0 & 0.40 & 7363.0 \\
\hline
\end{tabular}

\subsection{Other Consistency Tests}

As the HEC-RAS model requires a certain amount of input data, a sensitivity analysis was carried out in order to quantify the importance of the different involved quantities $[18,60]$. In the current study, breach formation refers to several parameters, including breach width, breach slope, and the time of breach formation. While for the propagation of the flood wave downstream, a breach involves several physical and hydrodynamic 
parameters, such as flow velocity, width, and height of the flood wave. For this effect, in order to highlight the influence of the breach formation parameters on the flood wave's physical and hydrodynamic parameters associated with a dam-failure flood, a sensitivity analysis method of four adjustments $(-50 \%,-25 \%,+25 \%$, and $+50 \%)$ was used for each of the selected sites at risk of flooding. In this sensitivity analysis, the adjustments of the flood hydrograph also were applied to perform the hydrological modeling for four adjustments $(-50 \%,-25 \%,+25 \%$, and $+50 \%)[60,61]$. The application of this method aims to thoroughly clarify the trend of each breach parameter and flood hydrograph on each parameter of the flood wave in every downstream section selected along the flood course.

\section{Results}

\subsection{Estimate of Dam Breach Parameters}

Dam breach parameters, including average breach width, breach side slope, and failure time, were predicted. After computing these parameters using the available methods in HEC-RAS, the obtained results were reviewed, and then a single predicted value was selected. These recommended values are shown in Table 1.

\subsubsection{Breach Width}

The dam breach parameters analysis described earlier showed that the Froehlich methods produced comparable results for this scenario, in which the average breach width $\left(B_{\text {avg }}\right)$ was relatively moderate $\left(B_{\text {avg }}=26 \mathrm{~m}\right)$. However, the Macdonald and LangridgeMonopolis (1984) method underestimated the observed breach width and showed the lowest values $\left(B_{\mathrm{avg}}=14 \mathrm{~m}\right)$. The Von Thun and Gillette method recorded the highest value $\left(B_{\text {avg }}=54 \mathrm{~m}\right)$. The prediction intervals developed through these methods were sobering for this case study where we sought to obtain a definitive result because the results obtained varied from small values for the dam to high values for breach width. Accordingly, the results of the Macdonald and Langridge-Monopolis method were excluded in this case study due to the low values.

\subsubsection{Breach Time}

Failure time predictions are summarized in Table 1. All the methods indicated a short time (40-47 $\mathrm{min}$ ) to empty the reservoir during the simulated dam failure event, except for the Macdonald and Langridge-Monopolis method, which predicted a slightly longer time $=1.1 \mathrm{~h}$. According to the failure time obtained in all prediction methods, the dam break analysis showed that the flood wave associated with the simulated dam break developed very fast. Accordingly, the consequences of this flash flooding are expected to be catastrophic and irreversible if a very early warning system is not installed for alerting the citizens inhabiting this flood risk zone.

\subsubsection{Flow Peak}

Peak outflow estimates are shown in Table 1, sorted in order of increasing peak outflow for the dam breach scenario. The lowest peak flow predictions were obtained using the method with the least parameters. The highest peak flows were predicted using equations that incorporated a significant dependence on breach parameters. According to this analysis, a convergence was observed between results obtained using the Froehlich methods [58,59] and those of the Von Thun and Gillete method [57], whose point flow values were $7841.12 \mathrm{~m}^{3} / \mathrm{s}, 7363.03 \mathrm{~m}^{3} / \mathrm{s}$, and $8767.87 \mathrm{~m}^{3} / \mathrm{s}$, respectively. However, a significant difference was detected between the results of these methods and the outputs of the Macdonald and Langridge-Monopolis method [56] $\left(\mathrm{Q}=4400.18 \mathrm{~m}^{3} / \mathrm{s}\right)$ (Table 1).

\subsection{Analysis of Dam-Breach Flood Scenario}

Hydrodynamics of the flood wave along the Yabous river during the simulated dam failure followed four steps (Figure 10). The first was upstream of the dam. The second, 
at the dam reservoir. The third, at the level of breach formation, and the fourth was downstream from right at the dam to the end of the river.

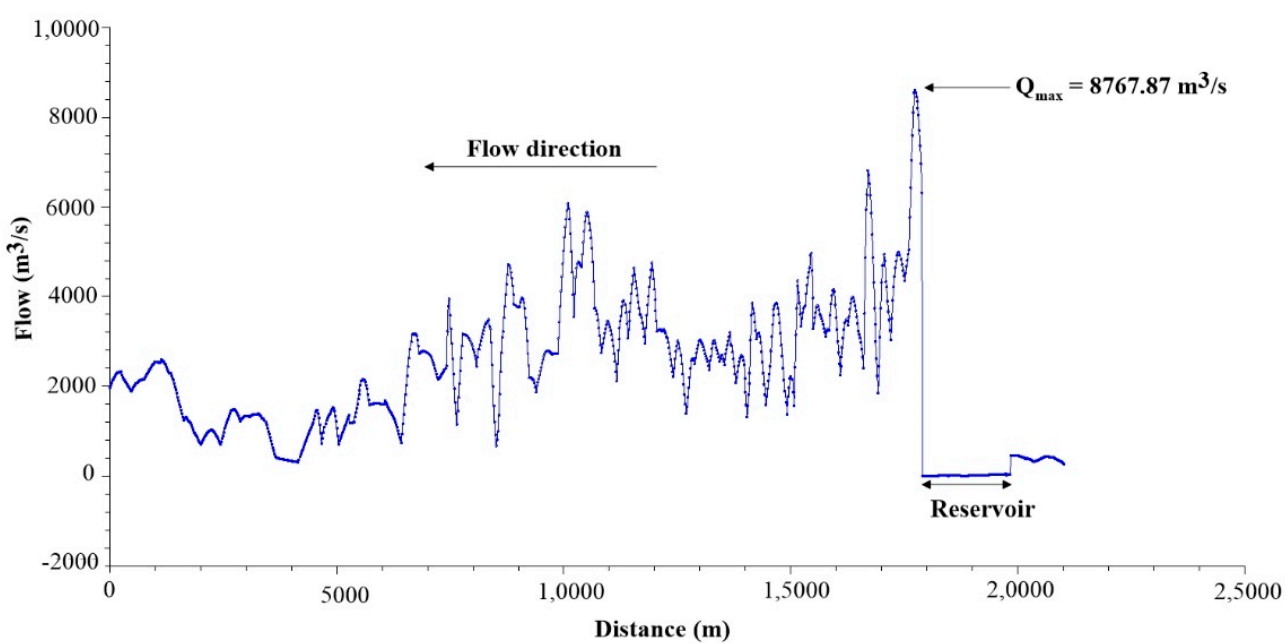

Figure 10. Flood hydrograph of dam-failure flood applied to Yabous dam using the Von Than and Gillet method.

The dynamics of the maximum flow velocity were mapped for the dam failure scenario depending on verified results of the one-dimensional hydrodynamic model (Figure 11). Regarding the flow velocity, two types of flows are distinguished during the Yabous dambreak flood. The velocity curve can be divided into three main parts: the parts $\left(I_{\mathrm{a}}, I_{\mathrm{b}}\right)$ reflected a torrential flow, while part (II) indicated a fluvial flow.

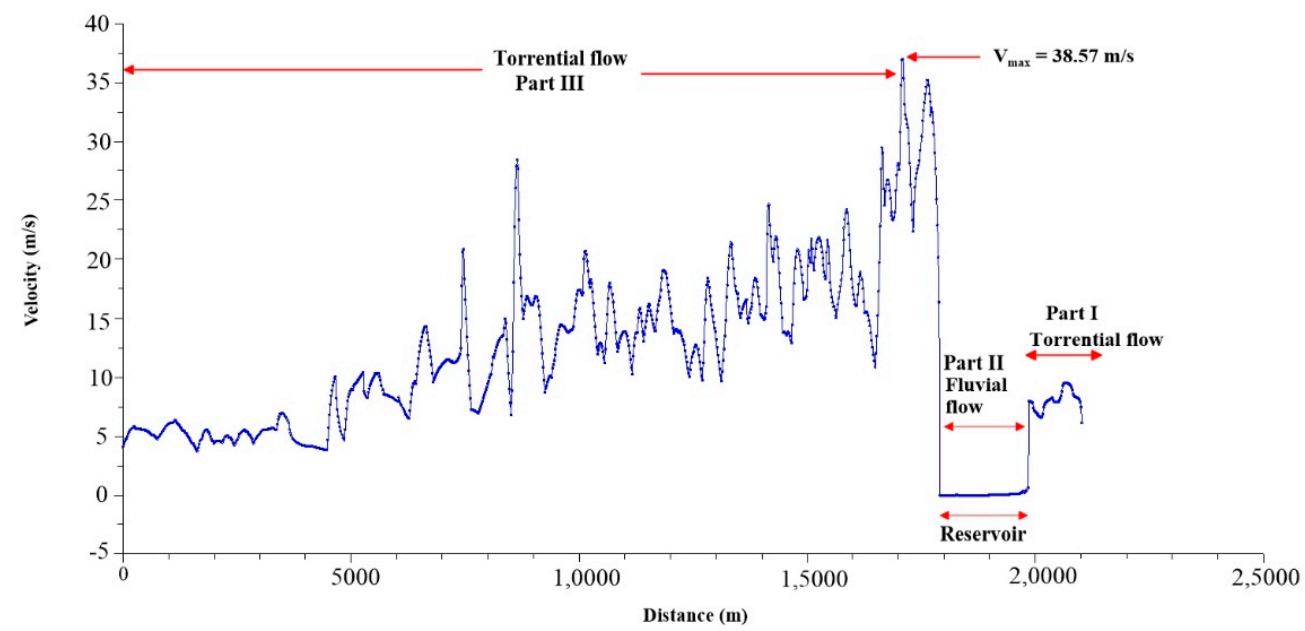

Figure 11. Dynamics of flow velocity during the dam-failure flood of Yabous dam along the river downstream.

Changes in the flood wave's width corresponded to the basin's geometry along the Yabous river (Figure 12). For steep slopes, narrow widths were recorded as the point of breach formation on the dam axis, whereas the large widths recorded at weak slopes can be related to the slowing down of water flooding at these slopes where the maximum width $\left(B_{\text {reservoir }}=1028.18 \mathrm{~m}\right)$ was recorded at the level of the dam reservoir, just a few seconds before the dam failure. At that moment, the height of the water in the dam reservoir was equal to the dam's height. The satellite image and the cross-section show water filling the reservoir behind the Yabous dam (Figure 12). The data represented in Figure 12 indicate a hydrodynamic trend in the opposite direction compared to data shown in Figures 10 and 11, which represent the flow and velocity of the flood wave before and 
during the dam failure. Therefore, we can argue that Figures 10 and 11 reflect the potential energy of the flood wave. In contrast, Figure 12 represents the quantitative energy of the flood wave at each point along the Yabous river.

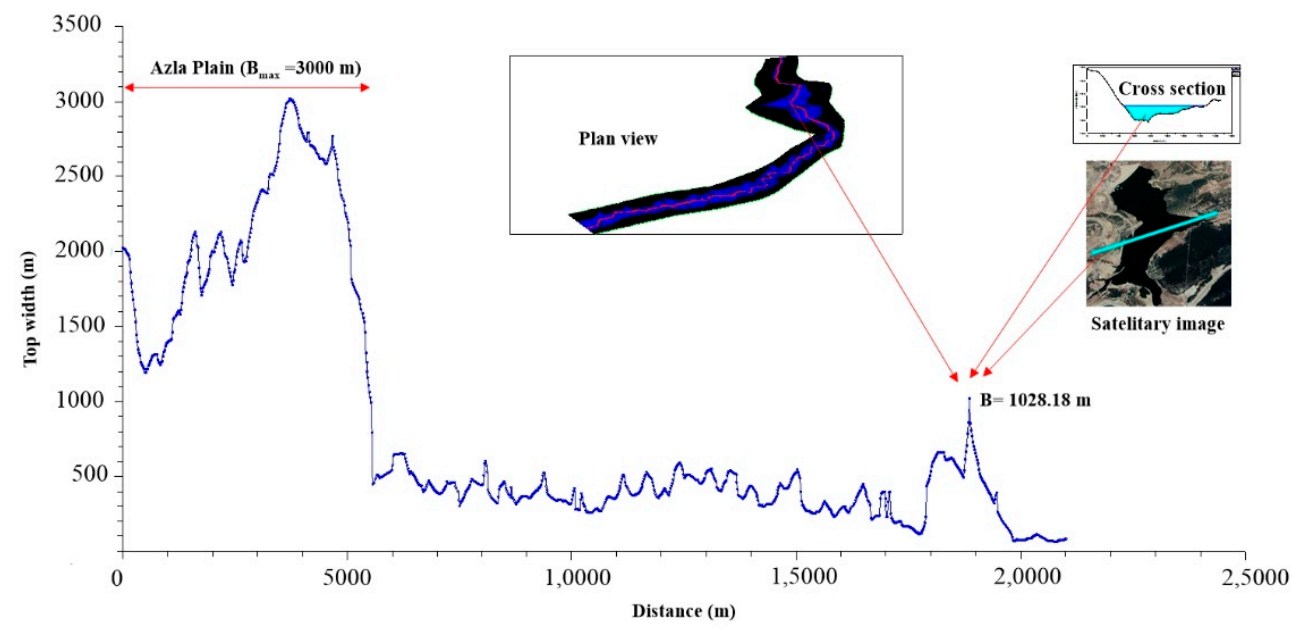

Figure 12. Hydrodynamic simulation of the width of the flood wave along Yabous river during a simulated dam-failure flood.

The profile of water current power evolved similarly with trends of water current shear stress, which represented the potential energy of the water during the flood. The two previous profiles were developing in the opposite direction to that of the surface (Figure 13). During the time of dam failure, no dynamic was recorded at the level of the dam reservoir, which is due to the stabilization of the water level in this part. However, the flow peak was observed at the level of the breach formation, where water was falling from the reservoir with the progressive formation of the breach. Meanwhile, irregularities were observed along the sections of the Yabous river for the three main factors, viz., the change in land slope (geometric), the type of soils/rock outcrops of this zone (geotechnical), and the type of flow either in load or in suspension (hydraulic).

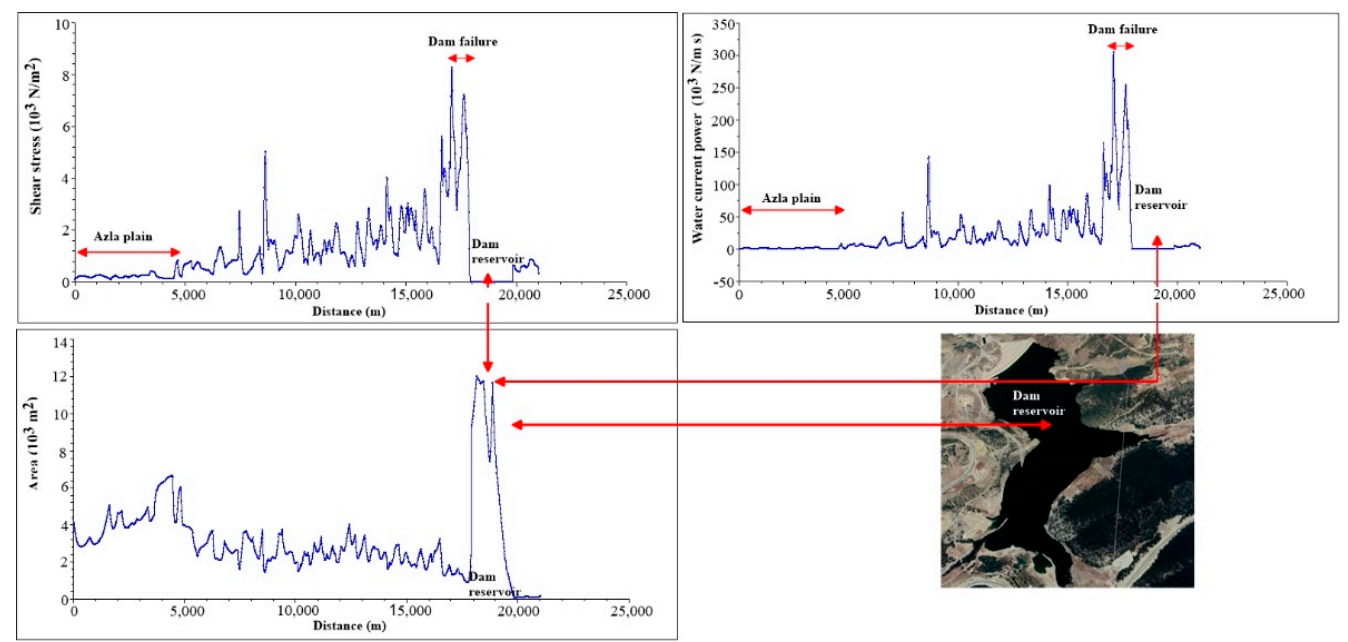

Figure 13. Power, shear stress, and water surface of water current associated with the flood wave along Yabous river during a simulated dam-break flood.

The analysis of flood wave propagation along the Yabous river during the simulated dam failure using the HEC-RAS model showed that the flood wave dynamics have four parts (Table 2, Figures 14 and 15). The first, before dam failure (time $=00: 00 \mathrm{~h}$ ), is where the reservoir is filled to the standard level. The second, after $30 \mathrm{~min}$ of dam failure, the 
flood wave arrived at the entrance of the Yabous village. The third, one hour after reaching Yabous entry, the flood wave reached the exit of the urban area. The fourth, during a time equal to 02:00 $\mathrm{h}$ after the dam failure, the reservoir was emptied completely.
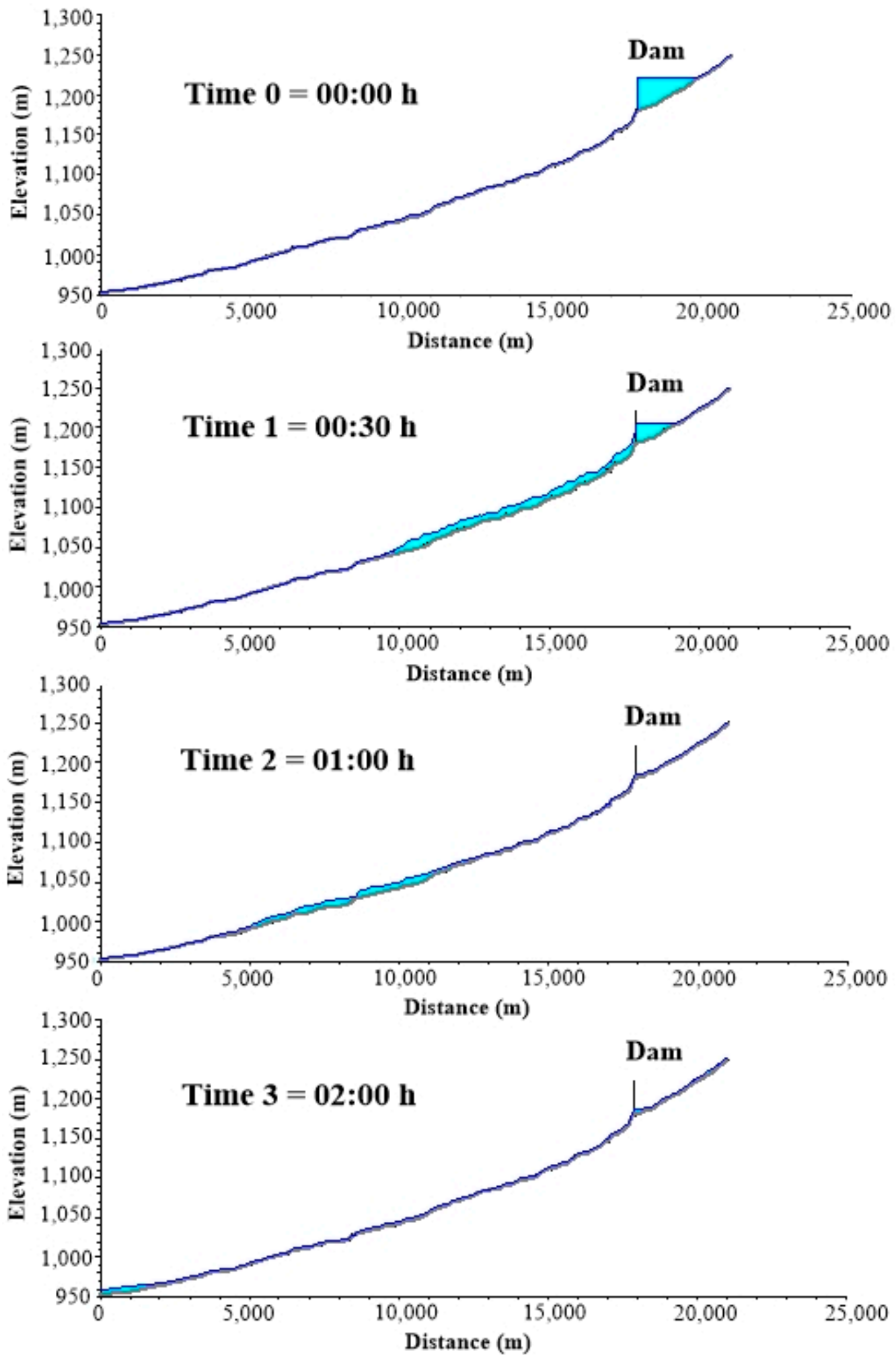

Figure 14. Longitudinal profile of the flood wave propagation before, during, and after the simulated flood of the Yabous river using 1-D HEC-RAS hydraulic model. 


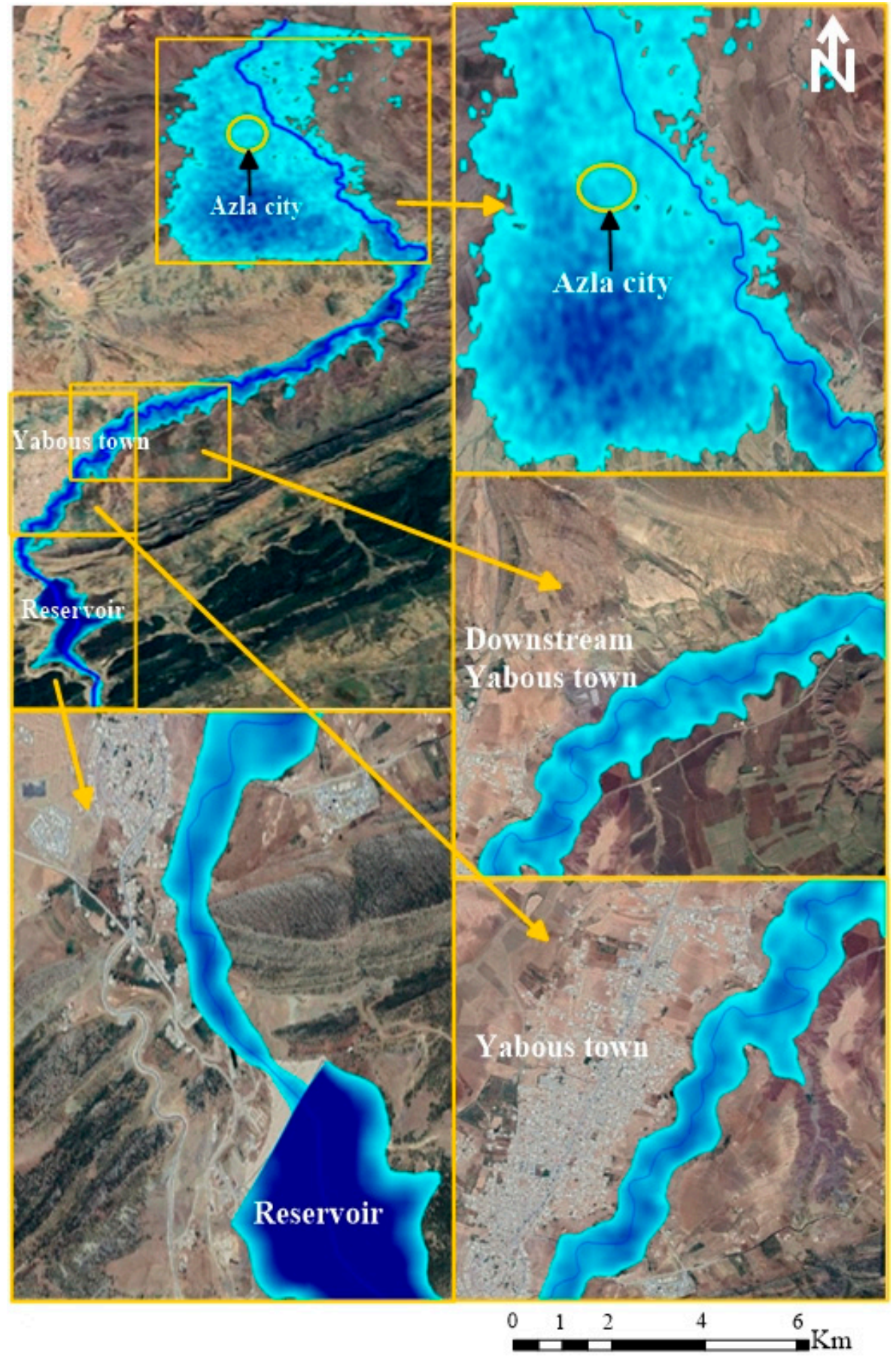

Figure 15. Satellite images showing flood risk zones downstream of the Yabous dam at high flood risk associated with simulated dam failure using 1-D HEC-RAS hydraulic model.

Eventually, the dead storage volume of the reservoir remained, and the flood wave started to fade. The frightening issue here is the high risk associated with this very quick discharge of a volume of 7 million $\mathrm{m}^{3}$ of the reservoir in only $90 \mathrm{~min}$. However, damage estimation was mostly based on water volume instead of depth [62]. It is worth mentioning that this eventuality represents a serious risk, since floods driven by dam failure can cause serious and irreversible disastrous consequences to human populations settled in downstream areas as their socio-economic and environmental livelihoods are devastated. Still, the travel time of a flood wave and the extent of flooding that would result from a dam failure should be predicted in order to prepare emergency action plans that would be used in the event of an actual dam failure [63]. Inundation maps developed in such simulation 
studies can serve as the core tool for decision making during the elaboration of emergency evacuation plans in the same way as in natural hazard assessment studies. These kinds of predictions have the potential to be a reference for future dam break inundation practical applications and research studies [34]. Table 2 includes the physical and hydrodynamic parameters of the flood wave for different sites selected along the Yabous river at the flood risk zone downstream of the dam (Figure 15) in order to assess the impact of the simulated dam-failure flood.

Table 2. The flood wave's physical and hydrodynamic parameters for different sites (S1-S7) were selected to assess the impact of a dam-break flood along the Yabous river in northeastern Algeria.

\begin{tabular}{cccccccc}
\hline & \multicolumn{5}{c}{ Sites } \\
\hline Flood Parameters & S1 & S2 & S3 & S4 & S5 & S6 & S7 \\
\hline Flood wave parameters & 17,945 & 17,207 & 16,590 & 14,546 & 14,461 & 2877 \\
Maximum flow 'Q' (m $\left.{ }^{3} / \mathrm{s}\right)$ & 8767.87 & 3603.6 & 3732.47 & 2427.49 & 1579.2 & 3265.5 & 3752.6 \\
Minimum main channel elevation (m) & 1180.00 & 1153.46 & 1137.28 & 1100.65 & 1100.13 & 972.38 & 968.78 \\
Water surface elevation (m) & 1194.05 & 1165.89 & 1146.97 & 1107.47 & 1106.98 & 974.17 & 970.44 \\
Energy grade line elevation (m) & 1223.87 & 1181.42 & 1155.62 & 1109.45 & 1107.72 & 974.33 & 970.58 \\
Energy grade line slope (m/m) & 0.043532 & 0.046506 & 0.036115 & 0.014848 & 0.007767 & 0.009170 & 0.007981 \\
Velocity (m/s) & 38.57 & 30.98 & 22.34 & 11.23 & 7.78 & 3.38 & 3.09 \\
Surface (m) & 990.72 & 1394.43 & 1757.35 & 1102.46 & 1139.24 & 2598.03 & 2560.41 \\
Width (m) & 129.96 & 213.85 & 357.17 & 354.88 & 312.54 & 2088.05 & 1376.86 \\
Height (m) & 14.05 & 12.43 & 9.69 & 6.82 & 6.85 & 1.79 & 1.66 \\
Froude Number & 2.75 & 2.84 & 2.38 & 1.44 & 1.01 & 0.89 & 0.83 \\
\hline
\end{tabular}

S1: axis of the dam, S2: upstream Yabous town, S3: bridge 1, S4: bridge 2, S5: downstream Yabous town, S6: upstream Azla city, S7: downstream Azla city.

\subsection{Sensitivity Analysis}

Figure 16 illustrates the variation of flood wave parameters (flow, width, and height) for four adjustments $( \pm 25$ and \pm 50$)$ of each breach parameter and four adjustments $( \pm 25$ and \pm 50 ) of the flood hydrograph in five sites downstream of the Yabous dam, with the initial dam failure analysis (without adjustments) given in the plot in green color as a reference value (0). An important deviation of all adjustments was observed for the breach parameters and flood hydrograph compared to the analysis of this scenario without adjustment (0). The null result was obtained in all parameters modeled in this analysis. This demonstrates the significant nature of breach parameters and flood movement on the physical parameters of the flood wave associated with dam-break flooding.

Similar trends were found between breach slope and breach width with the four adjustments ( $\pm 25 \%$ and $\pm 50 \%$ ), as shown in Figure 16 . Values of physical and hydrodynamic parameters of the flood wave on the five selected sites decreased with the increase in the adjustment values of breach parameters $(-25 \%,-50 \%)$. In contrast, the flood wave physical and hydrodynamic parameters increased with the increase in adjustment values of breach parameters (i.e., $+25 \%$ and $+50 \%$ adjustment). Despite the similar trends obtained between breach slope and breach width, differences still remain for the adjustment values. Values of breach width for the four adjustments were higher than those of breach slope. This indicates the large impact of the breach width values on flood wave parameters (Figures 16 and 17). The underestimation of breach width or breach lateral slope can lead to unsatisfactory results, according to Singh and Scarlatos [18], particularly in earthen dams, which consist of several building materials. The results obtained for the adjustments ( $\pm 25 \%$ and $\pm 50 \%$ ) of the flood hydrograph showed that the intensity of the floods upstream of the dam is generally low, and therefore the differential potential of the flood adjustments compared to adjustment (0) is also low on all of its parameters, such as flow, height and flood width (Figures 16 and 17). The adjustments $(+25$ and +50$)$ make small changes that appear on the three flood parameters after the dam rupture. On the other hand, the adjustment $(-50 \%)$ reveals that the hydrograph of the flood entering the dam without threat was not recorded. 
In order to demonstrate how a flood wave performed for different levels of adjustments $(-50 \%,-25,+25$, and $+50 \%)$ of the breach parameters (slope, width, formation time, and flood hydrography), relationships between flood wave flow, width, and height were tested using generalized linear mixed-effects models (GLMM), with Gaussian distribution error and 'identity' link. The selected sites downstream of Yabous dam were considered to be random effects, whereas flood wave variables (height and width) and breach adjustment levels were the fixed-effect factors. The GLMMs were carried out using the package \{nlme\} in R [64]. For each breach parameter (slope, width, and formation time), three GLMMs were created to test the effects of flood wave width on wave flow and wave height and the effect of flood wave height on wave flow. The R package \{ggplot2\} was employed in plotting the data of the dam breach parameters.

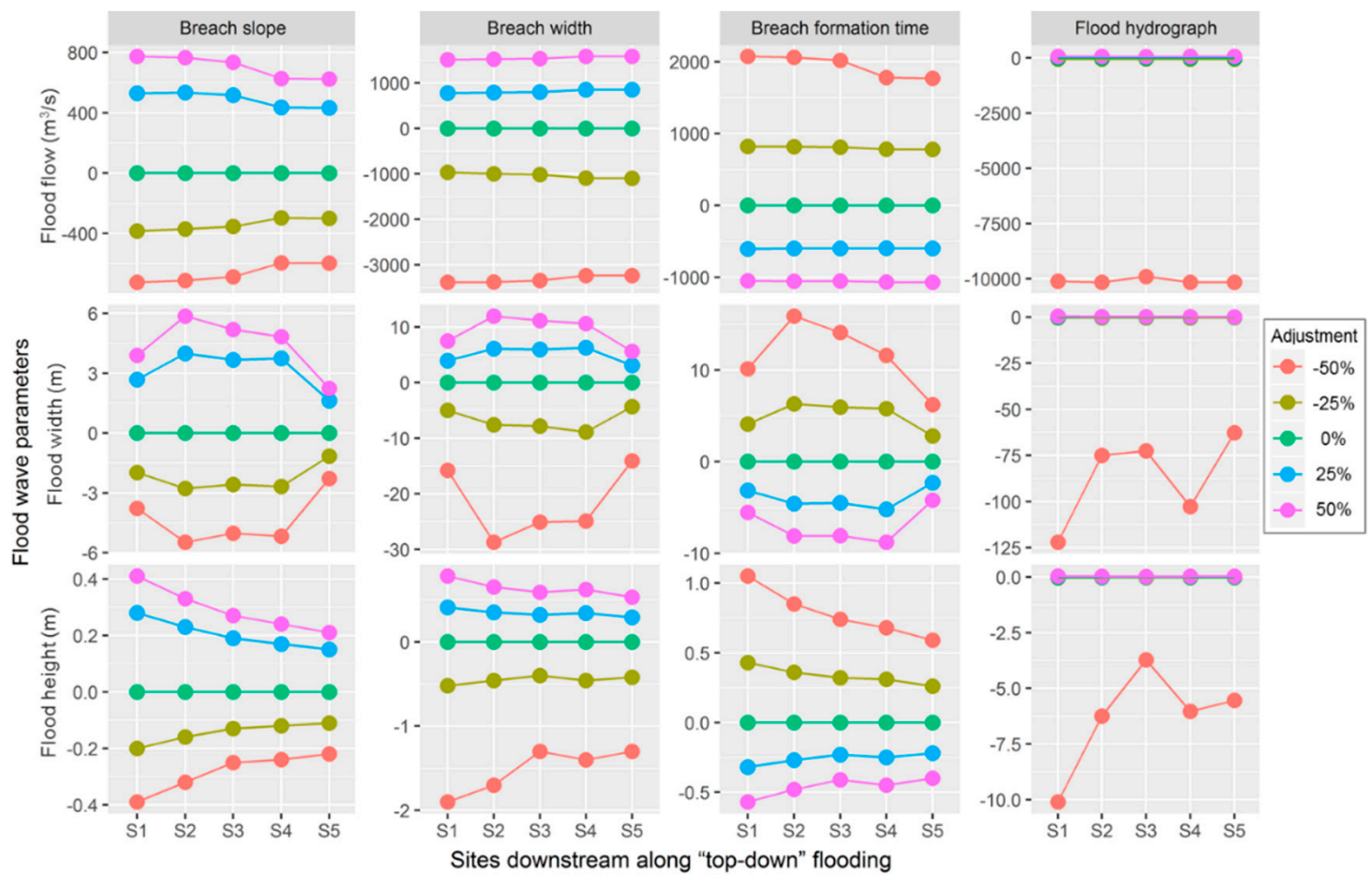

Figure 16. Results of sensitivity analysis of dam breach parameters (flood flow, width, and height) showing various adjustments of the breach slope, breach width, breach formation time, and flood hydrograph for different sites (S1-S5) selected along the Yabous river in northeastern Algeria for appraising the simulated dam-break flood. 

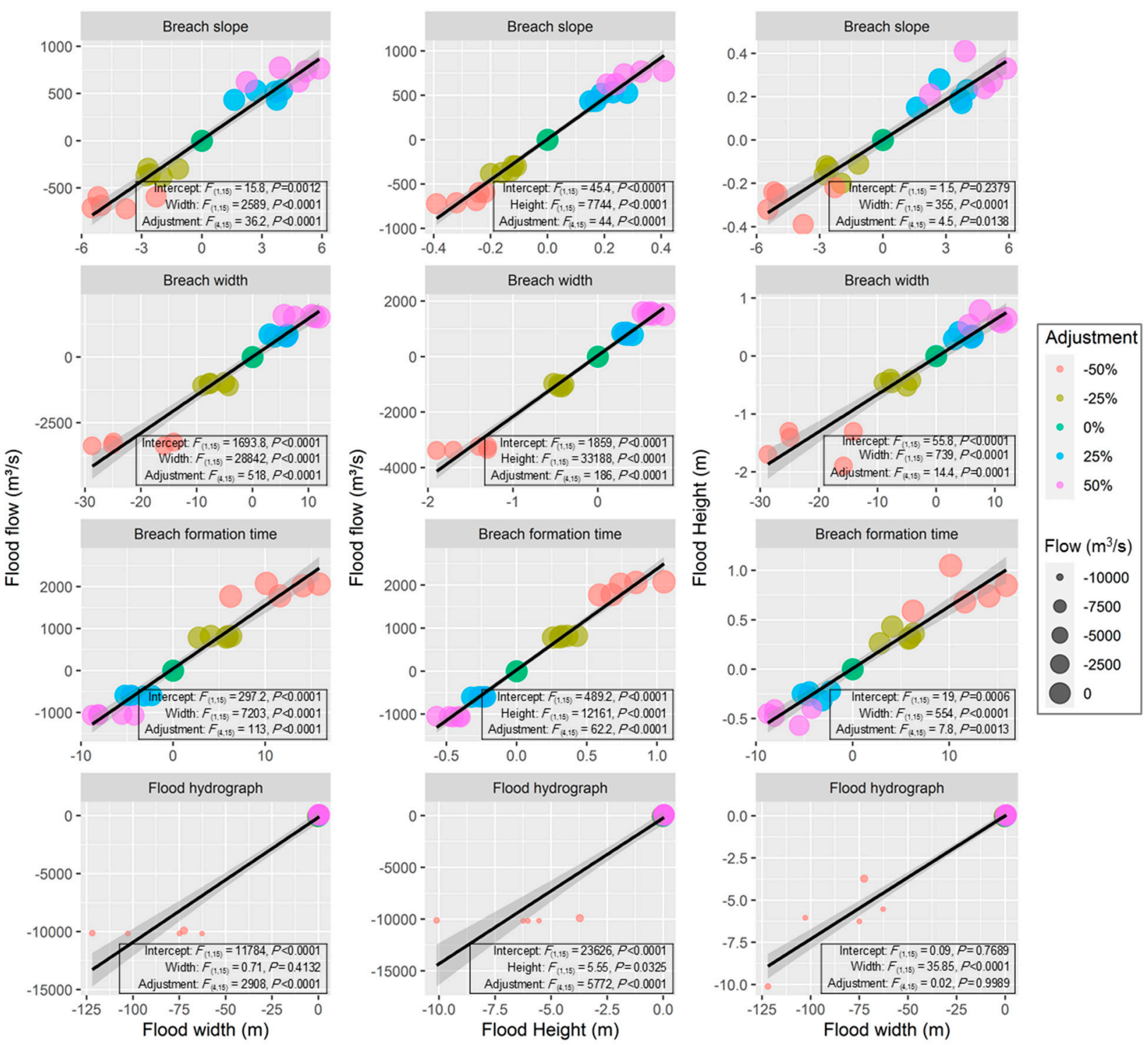

Figure 17. Relationships between simulated flood wave parameters (flood flow, width, and height) for various adjustments of the breach slope, breach width, breach formation time, and flood hydrograph simulated on the Yabous river in northeastern Algeria. Point sizes are set to water flow values and the color mapped to the levels of breach adjustments $(-50 \%,-25,+25$, and $+50 \%)$. The solid black lines represent linear regressions obtained by a Gaussian GLM (generalized linear model) fit with $95 \%$ confidence regions in light gray. Statistics reported in the boxes are results of fixed-effects terms of GLMMs, with F-statistics and $p$-values being type-II tests 'sequential'. Figures between brackets represent the numerator and denominator degrees of freedom, respectively.

\section{Discussion}

Four methods were used in this work including MacDonald and Langridge-Monopolis [56], Von Thun and Gillete [57], two by Froehlich [58,59], to determine the dam breach parameters. The results for the four methods for all parameters are different (Table 1). This difference can be explained by the lack of necessary data for the estimation of breach parameters. On the one hand, this reflects the reliability of the results obtained using the first three methods for the estimation of the breach parameters, including width, slope, and time of breach formation, and the simulation of flood wave propagation downstream following dam failure, on the other hand. The Macdonald and Langridge-Monopolis' method can no longer be adopted for a full study because of its aberrant and unrealistic results. Overall, Froehlich's methods showed good results in the field. They remained the best methods 
in this field, given the high number of real dam failure cases (63) used while predicting dam breach parameters, and because they are the most suitable for earthen dams [65]. The methods offered by Froehlich $(1995,2008)$ distinctly had the best prediction performance in the uncertainty analysis (Table 1). These methods had the smallest mean prediction error and the narrowest prediction interval by a significant margin $[23,66]$. The results of Von Thun and Gillete's method highlighted the worst flood case with a high flow level $\left(\mathrm{Q}=8767.87 \mathrm{~m}^{3} / \mathrm{s}\right)$ (Figure 10). This clearly indicates the limits of the risk zone downstream of the dam. The dam breach scenario proved to be a large event when analyzed by this method, so the peak outflow is expected to occur when the breach has reached its maximum size before the occurrence of a significant drawdown in the reservoir.

The hydrodynamics of the flood wave along the Yabous river during the simulated dam failure followed four steps. For step (1), a weak hydrodynamic simulation of the flood wave upstream of the dam was represented by a flow hydrograph given to the HEC-RAS model as a condition at the upstream limit with a flood rate (Qmax $\left.=485 \mathrm{~m}^{3} / \mathrm{s}\right)$. For step (2), no water dynamics were observed at the entire length of the dam reservoir because of the stability of the water level in the reservoir. In step (3), water discharge began at the dam crest during the dam break with a very slow flow. A significant development was recorded during the breach formation. This reflects the discharge of reservoir waters in the event of a rupture on a small breach that begins to form gradually during the dam rupture, where flow recorded a peak $\left(\mathrm{Qmax}=8767.87 \mathrm{~m}^{3} / \mathrm{s}\right)$. Given the large water quantity discharged over the dam crest, the propagation of the flood wave downstream of the dam is seriously hazardous and may have irreversible and disastrous consequences on urban areas, local populations, and the environment, with heavy economic losses [28]. For step (4), the dynamics of the flood wave downstream of the dam were simulated. This is most likely because the slope changes along the Yabous river, on the one hand. On the other hand, the basin section widens for each point of the river. According to the time of breach formation $(0.47 \mathrm{~h})$ and the geometry of the breach (flood width $=54 \mathrm{~m}$, slope $=0.5)$, the flow peak of the flood wave propagated very quickly downstream (Figure 10).

Regarding the flow velocity, two types of flows were distinguished during the Yabous dam-break flood $\left(I_{\mathrm{a}, \mathrm{b}}\right.$, and II). Part $I_{\mathrm{a}}$ represents the flood hydrograph given to the model as a condition at the upstream limit (S0). Moreover, it extended from section (S0) to the beginning of the dam reservoir with an average velocity $(V=9 \mathrm{~m} / \mathrm{s})$. For part II, it represented the fluvial flow velocity over the length of the dam dike with almost zero velocity. This flow resulted from the dissipation of flow energy by the stable water of the dam reservoir. Regarding part $\mathrm{I}_{\mathrm{b}}$, it indicated the torrential flow, which reflects the potential energy of the flood wave from the formation of the breach of the dam to the final section of the study area (Figure 11). The flow torrentiality is due to the change in the slope of the river on the whole part $\left(I_{b}\right)$. Indeed, the flow velocity increases rapidly in the wave tip zone, where the flow resistance dominates $[67,68]$. High-velocity peaks represent steep slopes, where flow speed recorded the highest velocity at the level of the breach formation $(V \max =38.57 \mathrm{~m} / \mathrm{s})$. The low peaks represent the weak slopes where small reservoirs occurred naturally and contributed to the dissipation of water flow on the river. The flood wave velocity shows a better match with the DEM model implanted in HEC-RAS. This analysis can provide a reasonable approximation of the impacts of a flood wave on areas located downstream in the event of dam failure. Thus, this information is essential for flood hazard classification and developing emergency action plans [68].

The simulation of the flood wave propagation downstream of the Yabous river was carried out using the 1-D HEC-RAS model, which delineated the zone that can be affected by this flood wave downstream of the dam in the case of the latter's failure. The flood wave related to dam failure was recorded at the breach level with a flow point of Qmax $=8767.87 \mathrm{~m}^{3} / \mathrm{s}$, and this reflects the impact of this flood downstream of the dam (Table 2). Subsequently, this wave arrived at site $S 2\left(\mathrm{~N}^{\circ} 17207\right)$, which represents the beginning of Yabous village with a flow and a flood-wave width of $Q=3603.60 \mathrm{~m}^{3} / \mathrm{s}$ and $B_{\text {Flood }}=213.85 \mathrm{~m}$, respectively. This width confirms that the upstream limit of the 
Yabous village is far from this flood (Figure 15). The flood wave reached site S3 at the first bridge with four square openings $(3 \mathrm{~m} \times 3 \mathrm{~m})$ with a flow of $\mathrm{Q}=3732.47 \mathrm{~m}^{3} / \mathrm{s}$, flow width $=357.17 \mathrm{~m}$, and a height $=9.69 \mathrm{~m}$, which is expected to completely submerge the bridge (Table 2). This demonstrates the violent and destructive impact of the rapid flood resulting from dam failure. The wave arrived at the second three-opening bridge $(3 \mathrm{~m} \times 3 \mathrm{~m})$ located downstream the village (S4: $\left.\mathrm{N}^{\circ} 14546\right)$ with a flow $\mathrm{Q}=2427.49 \mathrm{~m}^{3} / \mathrm{s}$ and a height $\mathrm{H}=6.82 \mathrm{~m}$, which may induce the total damage of this bridge and, thus, cuts the road connecting the town of Yabous to the Khenchela City. The flooding caused by dam failures in an urban area is a complex phenomenon, specifically with the appearance of structural ruptures, suspended debris, and incisal currents, especially when associated with a very unstable and turbulent flood flow [6,69]. It could be possible that the town of Yabous is a little far from the flood generated by the rupture of the dam, but the village of Azla ( $\mathrm{N}^{\circ} 2877,2480$ ), which is $15 \mathrm{~km}$ from the dam, will be completely submerged, and this is due to the geometry of this village being almost the same altitude compared to the wadi of Yabous bed. The consequences could be really destructive and irreversible on the urban and the social side (Figure 15). In addition to these disasters, Figure 15 can also reveal the destruction of the largest Yabous plain, as approximately $80 \%$ of this plain could be submerged (Figure 15). The consequences of this flood do not stop here; the road of this village will also be destroyed. According to Figure 15, the only way to deal with this flood is to make a good alarm system that responds to this type of risk, given the fact that the flood will reach the village in about two hours (02 h) (Figure 14).

The flood wave arrived at Azla city with a flow $=3265.5 \mathrm{~m}^{3} / \mathrm{s}$ and width $=2088 \mathrm{~m}$. These findings demonstrate the real need to protect the local population and their livelihood from possible flood events generated by dam failure. Heavy human and economic losses are expected with the rapid passage of the flood wave. This includes the partial destruction of the urban zone, agricultural lands, and crops located downstream. The analysis also demonstrated that because of the dam-break flood event, the town of Yabous may lose some houses built on the left edge of the Yabous river (Figure 15). Despite the acceptable protection status of Yabous town against this simulated flood, the flood wave is expected to seriously harm the region at various levels, such as all the flooded agricultural lands, which are expected to be severely destroyed and lose their productivity features. Indeed, crop yields are destroyed, too. Agricultural activities and livestock farming represent a large part of this area's population income. More than 80,000 different orchards trees $(80 \%$ are apple) can be affected by this flood event.

Ecologically, the passage of flood waves is often associated with detritus deposits and drastic changes in soil characteristics. All this is expected to disrupt the behavior of fauna and flora and the entire ecosystem functioning of the region [70-73]. The negative effects on flora and riparian river habitats are projected to be severe and most likely persistent throughout the risk area [74]. Flood waves can influence ecosystem processes, affecting within-channel productivity, particulate organic matter retention, decomposition, nutrient transformations, and microbial processes [75]. It can also influence surface water and groundwater quality and recharge [76]; flood waves may also cause 'sand slugs,' alter channel morphology, scour substrata, remove in situ basal resources, such as macrophytes, detritus, and translocate, injure or kill biota, and affect the relative importance of autochthonous and allochthonous carbon sources [77]. In general, floods also alter water quality [78] and facilitate the spread of non-native and invasive species [79]. Floods waves vary greatly in their character and their impact, as does the vulnerability of the populations they affect. It is also known that the areas at greatest risk are located downstream from a dam [80]. The health impacts of floods waves can be direct or indirect and depend upon various factors, including the characteristics of the flood hazard, patterns of exposure, and the underlying vulnerability of the population. The health impacts of a particular flood event are context-specific and are very different between developed and developing countries, ranging from injuries to epidemiological consequences, which will have the effect of increased mortality [81]. 
Simulation analysis can measure the extent and the intensity of the damage caused by the deposits of solid residues (tailings, metals, plastics, woods, etc.) transported with the flood wave, of which the loss of vegetation would trigger bottom-up land degradation [82]. Consequently, the loss of soil stability and runoff control increases the risk of further geomorphological disturbances, including landslides, bank ruptures, and massive creep movements. To this end, the priority is given to mitigation measures to deal with this type of risk through policy making that ensures a strict application of integrated environmental impact assessments and preventive monitoring. This should avoid or significantly minimize dam failure impacts [74].

In the case of the Yabous dam, the damage that the flood can cause to the dam body building and the type of construction materials, especially of the core (usually clay), can increase the breach width once the flood has dumped on the dam crest. This is expected, therefore, to increase the flood flow while reducing the flood propagation time. The resistance of materials, regardless of the friction angle and coefficient of cohesion, can be considered in the modeling flood scenario. The low resistance of materials causes its easy removal during the flooding on the ridge, which causes an increase in the breach width and lateral slope. Thereby, the rate of eroded materials displaced from the dam body to downstream areas of the dam and river increases as a laden flow [23].

Regardless of breach parameters (slope, width, formation time, and flood hydrography), the GLMMs indicated that the flood wave flow increased significantly with the increase in wave height $(p<0.0001)$ and wave width $(p<0.0001)$. The effect of the flood wave width of the variation in wave height in the five selected sites were highly significant $(p<0.0001)$ for all breach parameters (Figure 17). The statistical models showed that the variables of wave flow, both the physical and hydrodynamic, differed significantly among breach adjustment levels ( $p<0.001)$, with values of flood wave variables increasing along a negative-to-positive gradient of adjustment levels ( $-50-50 \%)$ of breach slope and width. However, flood wave flow, height, and width increased inversely to the increase in the breach adjustment levels of breach formation time (Figure 17).

Indeed, the physical and hydrodynamic parameters of the breach slope and the breach width went in the opposite direction compared to the breach formation time (Figure 16). Accordingly, the more the adjustment values of the breach formation time move in the negative direction (i.e., $25 \%$ and $-50 \%$ ), the higher the physical parameters of the breach formation time are. However, the physical and hydrodynamic parameters of the flood wave at the five selected sites decreased for the positive adjustments $(+25 \%$ and $+50 \%)$ of the breach formation times (Figure 17). However, the adjustments of the flood hydrograph ( $\pm 25 \%$ and $\pm 50 \%$ ) have shown that the flood can only increase the possible risk of rupture of the dam whose spillway does not support these flows that exceed the flow rate for which this structure was designed (Figure 16). However, this flood with the adjustments $( \pm 25 \%$ and $\pm 50 \%$ ) does not have a great influence on the flood parameters downstream of the dam (Figures 16 and 17). This is due to the large difference in the peak flow that leaves the dam in the event of a break compared to the flow of the flood entering the dam.

As a result, the actual dam break mechanisms are not well understood. Neither the current physical models nor the empirical models have been able to fully explain the mechanisms and impacts of dam failures [83]. For practical applications, these results contribute to the simple identification of the most prominent breach parameters so that we can prioritize resources towards a more precise estimation of their values $[84,85]$. Otherwise, in earthen dams, several technical factors can influence the general parameters of the breach formation. The first example to mention is the volume of the dam reservoir; the larger the volume, the more the breach shape increases [86]. The second, the type of clay used for the dike core; the more plastic the clay used is (cohesion and friction nail), the more the dam dike will resist the various floods on the dike crest. Therefore, the resulting breach shape is weak $[87,88]$. The third, the thickness of the filters upstream and downstream of the dike core; a wide filter thickness will induce the phenomenon of erosion in the event of a flood spill on the crest. This will systematically give a large breach shape [89]. The 
fourth is the amount of compaction applied on the layers of the dike material during its construction [90]. The fifth, the thickness of the layer of the material used for the realization of the dike and, in particular, the clay material; the lower the thickness of the layer, the more the dike body can resist the flood spill on the dam crest [91]. The sixth, the number of the layers watering the dam material (water content), especially the core material (clay) [90]. Additionally, the seventh is the protection of upstream and downstream embankments [92]. All these factors have an influence on the general dimensions of the breach (slope, width, and height); therefore, the latter can directly influence positively or negatively physical parameters of the flood wave. In general, the physical parameters of the flood wave are greatly influenced by the width of the breach and the slope of the breach, while it remains essentially insensitive to the time of breach formation [93,94]. In return for smaller reservoirs (a larger breach), the formation time has more influence on the outflow than the width of the breach. To this end, successful proof has been established concerning the approval and significance of these breach parameters on the development of the physical parameters of the flood in the event of a dam failure.

\section{Conclusions}

Dam-break floods cause truly catastrophic and irreparable environmental, social, and economic consequences. In order to mitigate flood risks, prior knowledge of flooding hazards is required. The present study demonstrated the effectiveness of the HEC-RAS 1-D model in simulating the propagation of flood waves downstream of the dam in the event of dam failure. Our findings revealed that the maximum flow of the Yabous dam-break flood at the level of the breach was $8768 \mathrm{~m}^{3} / \mathrm{s}$, which attenuated gradually along the Yabous river, where it recorded a flow of $1972.7 \mathrm{~m}^{3} / \mathrm{s}$ at $3.3 \mathrm{~km}$ from the dam. According to Von Thun and Gillette's method, the dam will run out of water in a very short time ( $\sim 47 \mathrm{~min})$, which stresses the need to install a fast and efficient alarm system. According to the risk map, it turned out that, despite the fact that the village of Yabous is predominantly far from flood waves, severe environmental and economic consequences could potentially occur, in particular the damage of two bridges and the destruction of the agricultural land.

The interrelationships and contribution rates of the model input parameters are studied by using the sensitivity analysis, performed on three breach parameters, i.e., width, slope, and training time, for four adjustments $(-25 \%,-50 \%,+25 \%$, and $+50 \%)$ over five sites located at an altitudinal gradient downstream of the dam. Sensitivity analysis highlighted the significant impact of breach parameters on the dynamic of the flood wave, either in the negative or positive direction following the adjustment. The analysis revealed that the influence of breach width and slope on the flood wave is in the same direction, on the one hand. On the other, it is in the opposite direction with respect to the time of breach formation. Nonetheless, the adjustments of the flood hydrograph $(-25 \%,-50 \%,+25 \%$, and $+50 \%$ ) have shown that the flood can only increase the possible risk of rupture of the dam whose spillway does not support these flows. That exceeds the flow rate by which this structure was designed. In addition, it provided valuable insights into the uncertainty of the input parameters selection for any dam design and dam feature of any work. The application of the sensitivity analysis method on dam-break flooding scenarios proved the significant association of the physical parameters of the flood wave with the parameters of breach formation. In the end, such flexibility is vital for climate change and measures that deal with the long-term consequences of water resource management. This study provides opportunities to monitor performance indicators and enhance effectiveness in our quest to manage water effectively and sustainably.

Author Contributions: Conceptualization, A.G. and H.A.A.; methodology, A.G. and H.A.A.; software, A.G. and H.C.; validation, A.B., L.B., and H.A.A.; formal analysis, J.B., A.E.K., and I.Z.; investigation, A.G. and A.A.; resources, A.E.K., J.B., and I.Z.; data curation, A.B., L.B., and H.C.; writing-original draft preparation, A.G., H.A.A., A.B., and L.B.; writing-review and editing, H.A.A., A.E.K., J.B., I.Z., and H.C.; visualization, A.B. and H.C.; supervision, L.B. and H.C.; project 
administration, A.B.; funding acquisition, H.A.A. All authors have read and agreed to the published version of the manuscript.

Funding: A. E. Krauklis' contribution was supported by the European Regional Development Fund within the Activity 1.1.1.2 "Post-doctoral Research Aid" of the Specific Aid Objective 1.1.1 of the Operational Programme "Growth and Employment" (Nr.1.1.1.2/VIAA/4/20/606).

Institutional Review Board Statement: Not Applicable.

Informed Consent Statement: Not Applicable.

Data Availability Statement: The data presented in this study are available on request from the corresponding author.

Acknowledgments: Many thanks are addressed to the DGRSDT (Directorate General of Scientific Research in Algeria) and the MESRS (Ministry of Higher Education and Scientific Research of Algeria) for their support. Many thanks are also addressed to the European Regional Development Fund within the Activity 1.1.1.2 "Post-doctoral Research Aid" of the Specific Aid Objective 1.1.1 of the Operational Programme "Growth and Employment" (Nr.1.1.1.2/VIAA/4/20/606) for their support.

Conflicts of Interest: The authors declare no conflict of interest.

\section{References}

1. Derdous, O.; Djemili, L.; Bouchehed, H.; Tachi, S.E. A GIS based approach for the prediction of the dam break flood hazard-A case study of Zardezas reservoir-Skikda, Algeria. J. Water Land Dev. 2015, 27, 15-20. [CrossRef]

2. Boussekine, M.; Djemili, L. Modelling approach for gravity dam break analysis. J. Water Land Dev. 2016, 30, 29-34. [CrossRef]

3. Berghout, A.; Meddi, M. Sediment transport modelling in Wadi Chemora during flood flow events. J. Water Land Dev. 2016, 31, 23-31. [CrossRef]

4. Wang, B.; Chen, Y.; Wu, C.; Dong, J.; Ma, X.; Song, J. Semi-analytical model for predicting peak discharge of dam-break flood. Hydrol. Processes 2016, 30, 3682-3691. [CrossRef]

5. Luino, F.; Tosatti, G.; Bonaria, V. Dam Failures in the 20th Century: Nearly 1000 Avoidable victims in Italy Alone. J. Environ. Sci. Eng. 2014, 3, 19-31.

6. Gaagai, A.; Boudoukha, A.; Benaabidate, L. Failure simulation of Babar dam-Algeria and its impact on the valley downstream section. J. Water Land Dev. 2020, 44, 75-89. [CrossRef]

7. Negm, A.; Bouderbala, A.; Chenchouni, H.; Barcelo, D. Water Resources in Algeria-Part I: Assessment of Surface and Groundwater; The Handbook of Environmental Chemistry Series; Springer: Cham, Germany, 2020. [CrossRef]

8. Schreider, S.Y.; Smith, D.I.; Jakeman, A.J. Climate Change Impacts on Urban Flooding. Clim. Change 2000, 47, 91-115. [CrossRef]

9. Nassopoulos, H.; Dumas, P.; Hallegatte, S. Adaptation to an uncertain climate change: Cost benefit analysis and robust decision making for dam dimensioning. Clim. Change 2012, 114, 497-508. [CrossRef]

10. Arar, A.; Chenchouni, H. How could geomatics promote our knowledge for environmental management in Eastern Algeria. J. Environ. Sci. Technol. 2012, 5, 291-305. [CrossRef]

11. ShahiriParsa, A.; Noori, M.; Heydari, M.; Rashidi, M. Floodplain zoning simulation by using HEC-RAS and CCHE2D models in the Sungai Maka river. Air Soil Water Res. 2016, 9, 55-62. [CrossRef]

12. Gaagai, A. Etude de L'évolution de la Qualité des Eaux du Barrage de Babar (Sud-Est Algérien) et L'impact de la Rupture de la Digue sur L'environnement. Ph.D. Thesis, University of Batna 2, Batna, Algeria, 2017. [CrossRef]

13. Fluixá-Sanmartín, J.; Morales-Torres, A.; Escuder-Bueno, I.; Paredes-Arquiola, J. Quantification of climate change impact on dam failure risk under hydrological scenarios: A case study from a Spanish dam. Nat. Hazards Earth Syst. Sci. 2019, 19, $2117-2139$. [CrossRef]

14. Lee, B.S.; You, G.J.Y. An assessment of long-term overtopping risk and optimal termination time of dam under climate change. J. Environ. Manag. 2013, 121, 57-71. [CrossRef] [PubMed]

15. Kundzewicz, Z.W.; Kanae, S.; Seneviratne, S.I.; Handmer, J.W.; Nicholls, N.; Peduzzi, P.; Mechler, R.; Bouwer, L.M.; Arnell, N.; Mach, K.J.; et al. Flood risk and climate change: Global and regional perspectives. Hydrol. Sci. J. 2014, 59, 1-28. [CrossRef]

16. Delenne, C.; Cappelaere, B.; Guinot, V. Uncertainty analysis of river flooding and dam failure risks using local sensitivity computations, Reliab. Eng. Syst. Saf. 2012, 107, 171-183. [CrossRef]

17. Guo, X.; Dias, D.; Pan, Q. Probabilistic stability analysis of an embankment dam considering soil spatial variability. Comput. Geotech. 2019, 113, 93-103. [CrossRef]

18. Singh, V.P.; Scarlatos, P.D. Analysis of Gradual Earth-Dam Failure. J. Hydraul. Eng. 1988, 114, 21-42. [CrossRef]

19. Israa, D.A.; Qassem, H.J.; Jasim, M.A. Sensitivity Analysis for Dam Breach Parameters Using Different Approaches for Hamrin Dam. Diyala J. Eng. Sci. 2021, 14, 90-97. [CrossRef]

20. Pektas, A.O.; Erdik, T. Peak discharge prediction due to embankment dam break by using sensitivity analysis-based ANN. KSCE J. Civ. Eng. 2014, 18, 1868-1876. [CrossRef] 
21. Xanthopoulos, T.; Koutitas, C. Numerical simulation of two-dimensional flood wave propagation due to dam failure. J. Hydraul. Res. 1976, 14, 321-331. [CrossRef]

22. Hervouet, J.M. A high-resolution 2-D dam-break model using parallelization. Hydrol. Processes 2000, 14, 2211-2230. [CrossRef]

23. Wahl, T.L. Uncertainty of predictions of embankment dam breach parameters. J. Hydraul. Eng. 2004, 130, 389. [CrossRef]

24. Sadrolashrafi, S.S.; Thamer, A.M.; Ahmad, R.B.M.; MajidK, K.; Amir, S. Integrated modeling for flood hazard mapping using watershed modeling system. Am. J. Eng. Appl. Sci. 2008, 1, 149-156. [CrossRef]

25. Mao, J.; Wang, S.; Ni, J.; Xi, C.; Wang, J. Management System for Dam-Break Hazard Mapping in a Complex Basin Environment ISPRS Int. J. Geo-Inf. 2017, 6, 162. [CrossRef]

26. Gee, M.; Brunner, G. Dam Break Flood Routing Using HEC-RAS and NWS-FLDWAV Conference. World Water Environ. Resour. Congr. 2005, 3, 6. [CrossRef]

27. Albu, L.M.; Enea, A.; Iosub, M.; Breabăn, L.G. Dam breach size comparison for flood simulations. A HEC-RAS based, gis approach for Drăcșani Lake, Sitna River, Romania. Water 2020, 12, 1090. [CrossRef]

28. Hafnaoui, M.A.; Madi, M.; Hachemi, A.; Farhi, Y. El Bayadh city against flash floods: Case study. Urban Water J. 2020, 17, 390-395. [CrossRef]

29. Tamm, O.; Tamm, T. Verification of a robust method for sizing and siting the small hydropower run-of-river plant potential by using GIS. Renew. Energy 2020, 155, 153-159. [CrossRef]

30. Oudni, A.; Dinar, H. Caractérisation Géologique et Géotechnique de la Cuvette du Barrage Tagharist. Master's Thesis, University of Oum El Bouaghi, Oum El Bouaghi, Algeria, 2016.

31. Chenchouni, H. Statuts de protection et de conservation des oiseaux recensés dans les Aurès et ses alentours (nord-est algérien). In Actes du Séminaire International sur la Biodiversité Faunistique en Zones Arides et Semi-Arides; Ouargla University: Ouargla, Algeria, 2010; pp. 56-75.

32. USACE. HEC-RAS Version 4.1 [Hydraulic Reference Manual]; Army Corps of Engineers Hydrologic Engineering Center, U.S. Army Corps of Engineers: Davis, CA, USA, 2008; Available online: https:/ /www.hec.usace.army.mil/software/hec-hms/ documentation/HEC-HMS_Applications_Guide_March2008.pdf (accessed on 13 January 2022).

33. Hu, H.H.; Walton, R. Advanced guidance on use of steady HEC-RAS. World Environ. Water Resour. Congr. 2008, 4, 12-16. [CrossRef]

34. Haltas, I.; Tayfur, G.; Elci, S. Two-dimensional numerical modeling of flood wave propagation in an urban area due to Urkmez dam-break, Izmir, Turkey. Nat. Hazards 2016, 81, 2103-2119. [CrossRef]

35. Chow, V.T. Open-Channel Hydraulics; McGraw-Hill: New York, NY, USA, 1959.

36. Brunner, G.W. HEC-RAS: River Analysis System User's Manual Version 5.0. 2016. Available online: https://www.hec.usace. army.mil/software/hec-ras/documentation/HEC-RAS\%205.0\%20Reference\%20Manual.pdf (accessed on 12 January 2022).

37. Zellou, B.; Rahali, H. Assessment of reduced-complexity landscape evolution model suitability to adequately simulate flood events in complex flow conditions. Nat. Hazards 2016, 86, 1-29. [CrossRef]

38. Zainalfikry, M.K.; Ab Ghani, A.; Zakaria, N.A.; Chan, N.W. HEC-RAS One-Dimensional Hydrodynamic Modelling for Recent Major Flood Events in Pahang River. In Proceedings of AICCE'19; Mohamed Nazri, F., Ed.; Springer: Cham, Switzerland; Berlin/Heidelberg, Germany, 2020; Volume 53. [CrossRef]

39. Vozinaki, A.E.K.; Morianou, G.G.; Alexakis, D.D.; Tsanis, I.K. Comparing 1D and combined 1D/2D hydraulic simulations using high resolution topographic data a case study of the Koiliaris basin. Greece Hydrol. Sci. J. 2016, 62, 642-646. [CrossRef]

40. Ahmad, B.; Hassan, Z.A. Flood map of Tupai River using combined 1D and 2D modelling. In Proceedings of the 3rd International Conference on Managing Rivers in the 21st Century: Sustainable Solutions for Global Crisis of Flooding, Pollution and Water Scarcity, Penang, Malaysia, 6-9 December 2011.

41. Leow, C.S.; Abdullah, R.; Zakaria, N.A.; Ghani, A.; Chang, C.K. Modelling urban river catchment: A case study in Malaysia. Proc. Inst. Civ. Eng. Water Manag. 2008, 162, 25-34. [CrossRef]

42. Dasallas, L.; Kim, Y.; An, H. Case Study of HEC-RAS 1D-2D Coupling Simulation: 2002 Baeksan Flood Event in Korea. Water 2019, 11, 2048. [CrossRef]

43. Brunner, G. HEC-RAS River Analysis System Hydraulic Reference Manual Version 5.0; USACE CEC: Davis, CA, USA, 2016.

44. Horritt, M.; Bates, P. Evaluation of 1D and 2D numerical models for predicting river flood inundation. J. Hydrol. 2002, 268, 87-99. [CrossRef]

45. Timbadiya, P.V.; Patel, P.L.; Porey, P.D. One-dimensional hydrodynamic modelling of flooding and stage hydrographs in the lower Tapi River in India. Curr. Sci. 2014, 106, 708-716.

46. Pramanik, N.; Panda, R.K.; Sen, D. One dimensional hydrodynamic modeling of river flow using DEM extracted river crosssections. J. Water Resour. Manag. 2010, 24, 835-852. [CrossRef]

47. Patel, S.B.; Mehta, D.J.; Yadav, S.M. One dimensional hydrodynamic flood modeling for Ambica River, South Gujarat. J. Emerg. Technol. Innov. Res. 2018, 5, 595-601.

48. Kostecki, S.; Banasiak, R. The Catastrophe of the Niedów Dam-The Causes of the Dam's Breach, Its Development, and Consequences. Water 2021, 13, 3254. [CrossRef]

49. Yerramilli, S. Potential Impact of Climate Changes on the Inundation Risk Levels in a Dam Break Scenario. ISPRS Int. J. Geo-Inf. 2013, 2, 110-134. [CrossRef] 
50. Brunner, G.W. Using HEC-RAS for Dam Break Studies. 2014. Available online: https:/ /www.hec.usace.army.mil/publications (accessed on 2 February 2020).

51. Mihu-Pintilie, A.; Cîmpianu, C.I.; Stoleriu, C.C.; Pérez, M.N.; Paveluc, L.E. Using High-Density LiDAR Data and 2D Streamflow Hydraulic Modeling to Improve Urban Flood Hazard Maps: A HEC-RAS Multi-Scenario Approach. Water 2019, 11, 1832. [CrossRef]

52. Menéndez-Pidal, I.; Martín, J.A.H.; Alonso-Muñoyerro, J.M.; Sanz, E. Real-Time Data and Flood Forecasting in Tagus Basin. A Case Study: Rosarito and El Burguillo Reservoirs from 8-12 March 2018. Water 2020, 12, 1004. [CrossRef]

53. Arseni, M.; Rosu, A.; Calmuc, M.; Calmuc, V.; Iticescu, C.; Georgescu, L.P. Development of Flood Risk and Hazard Maps for the Lower Course of the Siret River, Romania. Sustainability 2020, 12, 6588. [CrossRef]

54. Urziča, A.; Mihu-Pintilie, A.; Stoleriu, C.C.; Cîmpianu, C.I.; Hu, tanu, E.; Pricop, C.I.; Grozavu, A. Using 2D HEC-RAS Modeling and Embankment Dam Break Scenario for Assessing the Flood Control Capacity of a MultiReservoir System (NE Romania). Water 2021, 13, 57. [CrossRef]

55. Sammen, S.S.; Mohamed, T.A.; Ghazali, A.H.; Sidek, L.M.; El-Shafie, A. An evaluation of existent methods for estimation of embankment dam breach parameters. Nat. Hazards 2017, 87, 545-566. [CrossRef]

56. MacDonald, T.C.; Langridge-Monopolis, J. Breaching characteristics of dam failures. J. Hydraul. Eng. 1984, 110, 567-586. [CrossRef]

57. Von Thun, J.L.; Gillette, D.R. Guidance on Breach Parameters; Unpublished internal document; U.S. Bureau of Reclamation: Denver, CO, USA, 1990

58. Froehlich, D.C. Embankment dam breach parameters and their uncertainties. J. Hydraul. Eng. 2008, 134, 1708-1721. [CrossRef]

59. Froehlich, D.C. Peak Outflow from Breached Embankment Dam. J. Water Resour. Plan. Manag. 1995, 121, 90-97. [CrossRef]

60. Andreadakis, E.; Diakakis, M.; Vassilakis, E.; Deligiannakis, G.; Antoniadis, A.; Andriopoulos, P.; Spyrou, N.I.; Nikolopoulos, E.I. Unmanned Aerial Systems-Aided Post-Flood Peak Discharge Estimation in Ephemeral Streams. Remote Sens. 2020, $12,4183$. [CrossRef]

61. Kastridis, A.; Theodosiou, G.; Fotiadis, G. Investigation of Flood Management and Mitigation Measures in Ungauged NATURA Protected Watersheds. Hydrology 2021, 8, 170. [CrossRef]

62. Prettenthaler, F.; Amrusch, P.; Habsburg-Lothringen, C. Estimation of an absolute flood damage curve based on an Austrian case study under a dam breach Scenario. Nat. Hazards Earth Syst. Sci. 2010, 10, 881-894. [CrossRef]

63. McMahon, G.F. Developing dam-break flood zone ordinance. J. Water Resour. Plan. Manag. Div. 1981, 1072, 461-476. [CrossRef]

64. Core Team, R. R: A Language and Environment for Statistical Computing; R Foundation for Statistical Computing: Vienna, Austria, 2021; Available online: https:/ / www.R-project.org. (accessed on 16 January 2022).

65. Bellos, V.; Tsakiris, V.K.; Kopsiaftis, G.; Tsakiris, G. Propagating Dam Breach Parametric Uncertainty in a River Reach Using the HEC-RAS Software. Hydrology 2020, 7, 72. [CrossRef]

66. Shahrim, M.F.; Ros, F.C. Estimation of breach outflow hydrograph using selected regression breach equations. IOP Conf. Ser. Earth Environ. Sci. 2020, 476, 012129. [CrossRef]

67. Chanson, H. Application of the method of characteristics to the dam break wave problem. J. Hydraul. Res. 2009, 47, 41-49. [CrossRef]

68. Wang, B.; Chen, Y.; Wu, C.; Peng, Y.; Ma, X.; Song, J. Analytical solution of dam-break flood wave propagation in a dry sloped channel with an irregular-shaped cross-section. J. Hydro-Environ. Res. 2017, 14, 93-104. [CrossRef]

69. Gallegos, H.A.; Schubert, J.E.; Sanders, B.F. Structural damage prediction in a high-velocity urban dam-break flood: Field-scale assessment of predictive skill. J. Eng. Mech. 2012, 138, 1249-1262. [CrossRef]

70. Gaagai, A.; Boudoukha, A.; Boumezbeur, A.; Benaabidate, L. Hydrochemical characterization of surface water in the Babar watershed (Algeria) using environmetric techniques and time series analysis. Int. J. River Basin Manag. 2017, 15, 361-372. [CrossRef]

71. Tamm, T.; Noges, T.; Jarvet, A.; Bouraoui, F. Contributions of DOC from Surface and Groundflow into Lake Vortsjarv (Estonia) Hydrobiologia 2008, 599, 213-220. [CrossRef]

72. Aouissi, H.A.; Ababsa, M.; Gaagai, A.; Bouslama, Z.; Farhi, Y.; Chenchouni, H. Does melanin-based plumage coloration reflect health status of free-living birds in urban environments? Avian Res. 2021, 12, 45. [CrossRef]

73. Aouissi, H.A.; Petrişor, A.I.; Ababsa, M.; Boştenaru-Dan, M.; Tourki, M.; Bouslama, Z. Influence of Land Use on Avian Diversity in North African Urban Environments. Land 2021, 10, 434. [CrossRef]

74. Fernandes, G.W.; Goulart, F.F.; Ranieri, B.D.; Coelho, M.S.; Dales, K.; Boesche, N.; Bustamante, M.; Carvalho, F.A.; Carvalho, D.C.; Dirzo, R.; et al. Ecological and socio-economic impacts of the dam breach in Mariana, Brazil. Nat. Conserv. 2016, 14, 35-45. [CrossRef]

75. Leigh, C.; Bush, A.; Harrison, E.T.; Ho, S.S.; Luke, L.; Rolls, R.J.; Ledger, M.E. Ecological effects of extreme climatic events on riverine ecosystems: Insights from A ustralia. Freshw. Biol. 2015, 60, 2620-2638. [CrossRef]

76. Zhu, M.; Wang, S.; Kong, X.; Zheng, W.; Feng, W.; Zhang, X.; Yuan, R.; Song, X.; Sprenger, M. Interaction of Surface Water and Groundwater Influenced by Groundwater Over-Extraction, Waste Water Discharge and Water Transfer in Xiong'an New Area, China. Water 2019, 11, 539. [CrossRef] 
77. Bastos, R.F.; Lippi, D.L.; Gaspar, A.L.B.; Yogui, G.T.; Frédou, T.; Garcia, A.M.; Ferreira, B.P. Ontogeny drives allochthonous trophic support of snappers: Seascape connectivity along the mangrove-seagrass-coral reef continuum of a tropical marine protected area. Estuar. Coast. Shelf Sci. 2022, 264, 107591. [CrossRef]

78. Gholizadeh, M. Effects of floods on macroinvertebrate communities in the Zarin Gol River of northern Iran: Implications for water quality monitoring and biological assessment. Ecol. Processes 2021, 10, 46. [CrossRef]

79. Čuda, J.; Rumlerová, Z.; Brůna, J.; Skálová, H.; Pyšek, P. Floods affect the abundance of invasive Impatiens glandulifera and its spread from river corridors. Divers. Distrib. 2017, 23, 342-354. [CrossRef]

80. Du, W.; FitzGerald, G.J.; Clark, M.; Hou, X.Y. Health impacts of floods. Prehospital Disaster Med. 2010, 25, 265-272. [CrossRef]

81. Ahern, M.; Kovats, R.S.; Wilkinson, P.; Few, R.; Matthies, F. Global health impacts of floods: Epidemiologic evidence. Epidemiol. Rev. 2005, 27, 36-46. [CrossRef]

82. Hatje, V.; Pedreira, R.M.; de Rezende, C.E.; Schettini, C.A.F.; de Souza, G.C.; Marin, D.C.; Hackspacher, P.C. The environmental impacts of one of the largest tailing dam failures worldwide. Sci. Rep. 2017, 7, 10706. [CrossRef]

83. Xiong, Y. A Dam Break Analysis Using HEC-RAS. J. Water Resour. Prot. 2011, 3, 370-379. [CrossRef]

84. Dewals, B.; Erpicum, S.; Detrembleur, S.; Archambeau, P.; Pirotton, M. Failure of dams arranged in series or in complex. Nat. Hazards 2011, 56, 917-939. [CrossRef]

85. Bencedira, S.; Bechiri, O. Degradation of fuchsine acid using the $\mathrm{HP} 2 \mathrm{~W} 15 \mathrm{Mo} 3 \mathrm{Co} 2.5 \mathrm{O} 62,20 \mathrm{H}_{2} \mathrm{O} / \mathrm{H}_{2} \mathrm{O}_{2}$ system: Effect of organic and inorganic additives. Euro-Mediterr. J. Environ. Integr. 2021, 6, 60. [CrossRef]

86. Clague, J.J.; Evans, S.G. A Review of catastrophic drainage of moraine-dammed lakes in British Columbia. Quat. Sci. Rev. 2000, 19, 1763-1783. [CrossRef]

87. Al-Riffai, M.; Nistor, I. Impact and analysis of geotechnical processes on earth fill dam breaching. Nat. Hazards 2010, 55, 15-27. [CrossRef]

88. Al-Riffai, M.; Nistor, I.; Vanapalli, S.K.; Orendorff, B. Overtopping of earth embankments: Sensitivity analysis on dam breach parameters using two numerical models. In Proceedings of the 60th Canadian Geotechnical Conference, Ottawa, ON, Canada, 21-24 October 2007; pp. 1213-1220.

89. Minguez, R.; Delgado, F.; Escuder, I.; de Membrillera, M.G. Reliability assessment of granular filters in embankment dams. Int. J. Numer. Anal. Methods Geomech. 2006, 30, 1019-1037. [CrossRef]

90. Zhang, L.; Gelet, R.; Marot, D.; Smith, M.; Konrad, J.M. A method to assess the suffusion susceptibility of low permeability core soils in compacted dams based on construction data. Eur. J. Environ. Civ. Eng. 2018, 23, 626-644. [CrossRef]

91. Zhong, Q.M.; Chen, I.S.S.; Mei, I.S.A.; Cao, I.W. Numerical simulation of landslide dam breaching due to overtopping. Landslides 2017, 8, 321-332. [CrossRef]

92. Neilsen, M.L. Global sensitivity analysis of dam erosion models. In Proceedings of the 10th International Conference on Scientific Computing, Las Vegas, NV, USA, 22-25 July 2013.

93. Singh, K.P.; Snorrason, A. Sensitivity of outflow peaks and flood stages to the selection of dam breach parameters and simulation models. J. Hydrol. 1984, 68, 295-310. [CrossRef]

94. Dewals, B.J.; Archambeau, P.; Erpicum, S.; Detrembleur, S.; Pirotton, M. Sensitivity analysis of the peak outflow induced by the breaching of embankment dams. In Proceedings of the 14th German Dam Symposium \& 7th ICOLD European Club Dam Symposium, Munich, Germany, 17-19 September 2007; Rutschmann, P., Ed.; Technische Universität München: Munich, Germany, 2007; pp. 86-92. 